Scholarship Repository

University of Minnesota Law School

Articles

Faculty Scholarship

1997

\title{
Sentencing Principles in Theory and Practice
}

Richard Frase

University of Minnesota Law School, frase001@umn.edu

Follow this and additional works at: https://scholarship.law.umn.edu/faculty_articles

Part of the Law Commons

\section{Recommended Citation}

Richard Frase, Sentencing Principles in Theory and Practice, 22 CRIME \& JUST. 363 (1997), available at https://scholarship.law.umn.edu/faculty_articles/486.

This Article is brought to you for free and open access by the University of Minnesota Law School. It has been accepted for inclusion in the Faculty Scholarship collection by an authorized administrator of the Scholarship Repository. For more information, please contact lenzx009@umn.edu. 


\section{Richard S. Frase}

\section{Sentencing Principles in Theory and Practice}

ABSTRACT

In Norval Morris's "limiting retributivist" theory of punishment, considerations of "just deserts" set upper and occasionally lower limits on sentencing severity. Other purposes, including general deterrence, considerations of equality, and "parsimony," provide the necessary "finetuning." Proponents of just deserts, such as Andrew von Hirsch, give much greater weight to retributive and equality values and would allow almost no role for other sentencing goals in the determination of the severity of individual sentences. The relative severity of sentences must be closely linked to desert, and parsimony should only be considered in determining issues such as the overall severity of the sentencing scale. Minnesota's sentencing guidelines, in effect since 1980, are based on a theory of just deserts, but also give substantial weight to utilitarian sentencing purposes. This was true even of the original guidelines and is more true today. The theory of punishment that has evolved is quite similar to Morris's theory and quite different from von Hirsch's. Minnesota's fifteen-year experience with guidelines shows that Morris's theory of punishment is both theoretically sound and practically viable.

Norval Morris's theory of punishment is a theory of "limiting retributivism," in which concepts of "just deserts" set upper and occasionally lower limits on sentencing severity; within these broad outer limits, other purposes and principles provide the necessary "fine-tuning."

Richard S. Frase is Benjamin N. Berger Professor of Criminal Law at the University of Minnesota Law School. A preliminary version of this article was presented at a conference in honor of Norval Morris, entitled "Crime, Punishment, and Mental Health: Soundings for the Twenty-first Century," held at the University of Chicago Law School on October 28-29, 1994.

() 1997 by The University of Chicago. All rights reserved.

0192-3234/97/0022-0008\$02.00 
Such other purposes and principles include not only traditional crimecontrol purposes (deterrence, incapacitation, and rehabilitation) but also considerations of equality (uniformity) and a concept Morris calls "parsimony": a preference for the least severe alternative that will achieve the purposes of the particular sentence. However, Morris rejects coerced rehabilitation as a reason for imprisonment or for extending a prison term. $\mathrm{He}$ also rejects basing the type or duration of sentences on individual predictions of dangerousness, except in very limited situations. His later writings express strong support for sentencing guidelines, provided such guidelines are flexible, and prescribe intermediate sanctions as well as prison terms.

Proponents of just deserts, such as Andrew von Hirsch, give much greater weight to retributive and equality values. Indeed, von Hirsch would allow almost no role for other sentencing goals in the determination of individual sentences. Von Hirsch agrees with Morris that sentencing severity, and especially the use of incarceration, are excessive in the United States; however, von Hirsch believes that the concept of parsimony should only be used to determine absolute, not relative, sentencing severity (e.g., the maximum and minimum extremes of the punishment scale) and should not be considered at a case-specific level. Like Morris, he favors sentencing guidelines and believes that they should promote broader use of intermediate sanctions; but von Hirsch insists that the severity of sentences for different offenders must be closely linked to their deserts.

Minnesota's sentencing guidelines, in effect since 1980, are widely believed to be based primarily on a just-deserts sentencing theory. In fact, however, the guidelines have always given substantial weight to all traditional sentencing purposes: not only retribution and equality, but also crime-control goals and parsimony (especially in the use of state prison terms). This hybrid theory is evident even at the level of theory and formal rules; it is even more evident in practice.

Section I of this essay describes Morris's theory of punishment as it has evolved over the years. Section II summarizes von Hirsch's critique of key aspects of Morris's theory and presents the responses Morris has made, or which could be made, to those criticisms. In Section III, I describe the theory of punishment which has evolved under the Minnesota guidelines, both in theory and in practice. Section IV reviews and discusses the many ways in which the guidelines have implemented Morris's approach. Even the differences between the Minnesotan and Morris theories generally reflect practical considerations which Morris 
has often noted. I conclude that Minnesota's experience demonstrates the wisdom of Morris's theory of punishment, which is both theoretically sound and (as proved in Minnesota) practically viable over a substantial period of time.

\section{I: Morris's Theory of Punishment}

In his first book, The Habitual Criminal, published in 1951, Morris noted that the theories of criminal punishment being applied by judges and legislators were neither coherent nor stable over time (quoting a 1902 criminal law text, making the same point) (Morris 1951, p. 8). However, Morris insisted that specific purposes are being applied, consciously or not, and that an effort must be made to define them more precisely, to avoid the "fortuitousness" of widely disparate sentences imposed by different judges in similar cases (Morris 1951, p. 9). Two years later, Morris again noted that courts "have failed to develop any agreed principles or practices and that consequently judicial sentencing lacks uniformity and equality of application, is considerably capricious, and can be shown to fit neither the crime nor the criminal" (Morris 1953, p. 186). Morris presented sentencing data documenting the extent of existing disparities and proposed a number of reforms.

Thus at the outset of his career, Morris identified and began to address the interrelated problems of sentencing disparity and the conflicting purposes of, and at, sentencing. His earliest works also show his strong belief in the importance of relating sentencing theory to sentencing practice- "the actual functioning" of penal sanctions (Morris 1951, p. 16). Morris is an empiricist and a realist; he wants to know how judges and other practitioners think and act. Armed with this information, sentencing theory may reflect the accumulated wisdom of the past and may also avoid imposing highly unpopular rules which will only be circumvented in practice.

In his early critique of sentencing disparity, and also in some of his proposals for reform, Morris foreshadowed the revolution that would later transform the American sentencing process. Although most of his early reform proposals were intended to improve the quality of sentencing within the traditional "indeterminate" model (e.g., improved presentence investigations), several of his suggested reforms involved procedures that would later become central features of sentencing guidelines. Thus Morris assumed that sentences should be subject to appellate review (although at that time, such review was minimal in the British Commonwealth system and almost unheard of in the United 
States). He also insisted that trial courts should give reasons for their sentences, if an appeal was filed, and that the appeals court should likewise state reasons for its judgment. Morris further suggested that trial judges be provided with data on sentences imposed (by offense, offender age, and offender prior record), so that the judges could "see clearly where they stand in relation to their brethren" (Morris 1953, p. 200).

Morris's own theory of punishment began to emerge in his 1964 book, Studies in Criminal Law, coedited with Colin Howard. In an essay by Morris, entitled "Penal Sanctions and Human Rights," Morris argued that "power over a criminal's life should not be taken in excess of that which would be taken if reform were not considered one of our purposes" (Morris and Howard 1964, p. 175). Morris was thus one of the first mainstream writers to suggest the empirical and moral defects of the "rehabilitative ideal" of coerced, prison-based treatment linked to the timing of parole release (see also Allen 1964, pp. 25-41; Allen 1981). In addition, Morris's essay explicitly linked retributive sentencing goals to the human rights of defendants and implied that such rights place firm upper limits on the severity of punishments imposed to achieve crime-control purposes (Bottoms 1995, pp. 19, 22-23).

Morris continued his attack on the rehabilitative ideal in his 1970 book, The Honest Politician's Guide to Crime Control (Morris and Hawkins 1970, chap. 5). Morris questioned whether in-prison treatment programs are effective and argued strongly in favor of community-based sentencing and treatment. He also advocated much broader use of fines, in lieu of short custodial terms, and argued against statutes that impose mandatory minimum prison terms or place arbitrary limitations on probation eligibility (Morris and Hawkins 1970, pp. 11213, 115-24, 141-43; see also Morris 1977a, p. 150; Morris 1977b, pp. 279-80; Morris and Hawkins 1977, pp. 60-61; Morris 1993, p. 310).

\section{A. Emergence of Morris's Limiting Retributive Theory}

A more comprehensive theory of punishment was presented in 1974 in The Future of Imprisonment. Morris's theory was further developed in his 1976 lecture, "Punishment, Desert, and Rehabilitation" (Morris 1977a); in his 1982 book, Madness and the Criminal Law; and in his 1990 book (with Michael Tonry), Between Prison and Probation: Intermediate Punishments in a Rational Sentencing System.

In The Future of Imprisonment, Morris attempted to reconcile the numerous and often conflicting purposes of punishment within a theory 
of "limiting" retributivism, in which retributive or "just-deserts" values set upper, and occasionally lower, limits on the nature and severity of punishment. Although these principles were specifically addressed to the question of whether a prison term should be imposed, Morris indicated that they should also apply, "with suitable modifications," to prison duration and to other sentencing issues (Morris 1974, p. 59). His later writings on punishment have generally addressed both prison commitment and prison duration issues.

Morris's upper limits of desert are strict and explicit: "No sanction should be imposed greater than that which is 'deserved' for the last crime, or series of crimes" being sentenced (Morris 1974, pp. 60, 7377). However, he strongly emphasized that courts are permitted, but not obligated, to impose the maximum which the offender deserves (Morris 1974, p. 75).

In later writings, Morris extended the concept of desert to include at least some offender-based factors, especially the defendant's prior record of convictions (Morris 1982, pp. 151-52, 162-63, 184-86; Morris 1992, p. 145). ${ }^{1}$ Morris has also distinguished between the "societal" and "individual" faces of desert (Morris 1982, p. 161). The former determines the absolute upper and lower desert limits and "is a reflection of society's official view of what the criminal deserves; it is not finely tuned." However, within these outer limits, additional moral distinctions, based on the facts of the particular case, may be considered, along with other punishment goals and factors (Morris 1977b, pp. 275, 280-81; Morris 1982, pp. 151-52, 161, 168-69).

Morris's concept of "societal" desert was perhaps originally intended to correspond to the absolute upper and lower limits set by the legislature, for each offense, within which courts may consider the aggravating and mitigating circumstances of the particular case ("individual" desert). In a sentencing guidelines system such as Minnesota's (where presumptive sentencing ranges are often narrower than the statutory range), a second level of "societal" desert might be recognized: courts could routinely and somewhat loosely consider casespecific desert within the presumptive sentence range but would have to meet more exacting standards in order to "depart" and impose a sentence closer to the statutory minimum or maximum.

In Morris's view, desert sometimes also sets lower limits on punish-

\footnotetext{
'This article, although published in 1992, was based on Morris's 1982 Cardozo Lecture to the Association of the Bar of New York City.
} 
ment (i.e., minimum severity requirements); in his words, the sentence must not "depreciate the seriousness" of the current offense (Morris 1974, pp. 60, 78-79). This language was taken from the Model Penal Code (American Law Institute 1962, \$7.01(c)). Although Morris usually refers to this as a retributive concept (Morris 1974, p. 78; Morris 1977a, pp. 157-58; Morris 1982, p. 198), the code's language is also consistent with a long-term deterrent or norm-reinforcing function. Morris seemed to agree, noting that such minimum severity limits are needed because "[t]he criminal law has general behavioral standardsetting functions; it acts as a moral teacher" (Morris 1974, p. 78). In any case, whether for retributive reasons, norm-reinforcement, or both, Morris felt that strict lower limits on sentencing severity are only sometimes required (citing, as one example, a case of spousal homicide, where a prison term might be required even if the offender is no longer dangerous, and even if granting probation would not cause an immediate jump in homicide rates) (Morris 1974, p. 78). Finally, as noted earlier, Morris has consistently opposed mandatory minimum prison terms and arbitrary limits on probation eligibility (Morris and Hawkins 1970, pp. 141-43).

Within the upper and lower limits of desert, Morris envisioned a range of "not undeserved" penalties. In later writings, he characterizes these ranges as "overlapping and quite broad" (Morris 1982, p. 151). $\mathrm{He}$ also explicitly differentiated his own views from other desert-based theories by distinguishing between purposes of punishment which are "defining," those which are "limiting," and those which are only "guiding" principles (Morris 1977a, pp. 140-42; Morris 1982, pp. 182-87). Morris suggested that deterrent purposes could precisely define the proper punishment, but only if we knew much more than we now do about the deterrent effects of punishment. As for desert, however, he argued that this concept is inherently too imprecise (and perhaps also too lacking in political and philosophical consensus; Morris and Tonry 1990, pp. 86-89) to precisely define the sentence; it can only establish rough outer limits, an allowable sentencing range, beyond which penalties would be widely seen as clearly undeserved (i.e., either excessively severe or excessively lenient) (Morris 1977a, pp. 158-59; Morris 1982, pp. 198-99; Morris and Tonry 1990, pp. 104$5)$. Within those broad ranges of desert, other punishment goals, acting as "guiding principles," will interact to "fine-tune" the sentence. A guiding principle is defined as "a general value which should be re- 
spected unless other values sufficiently strongly justify its rejection in any given case" (Morris 1977a, p. 142).

\section{B. The Role of Various Nonretributive Sentencing Factors}

What, then, are the "guiding principles" in Morris's theory, which provide the necessary fine-tuning between retributive upper and lower limits, and what precise role does each play?

1. Rebabilitation. Morris was an early critic of the "rehabilitative ideal" of coerced, in-prison treatment linked to the timing of parole release (Morris 1964, p. 175). He greatly expanded on this critique in later writings (Morris and Hawkins 1970, chap. 5; Morris 1974, pp. 12-27; Morris 1977a, p. 139; Morris and Hawkins 1977, chap. 6). First, he argued, postprison risk cannot reliably be predicted based on in-prison behavior. Moreover, coerced in-prison treatment programs waste resources on unamenable subjects, while encouraging feigned cooperation which may actually preclude genuine reform. Finally, returning to the human rights theme of his earlier writings, Morris argued that such coercive treatment would be morally wrong even if it were effective.

Thus Morris concluded that rehabilitation is not a reason either to impose or to extend a prison sentence; furthermore, all in-prison treatment programs must be entirely voluntary and not linked to the timing of release. However, the inmate may be compelled to participate in such a treatment program long enough to "know what it is about" (Morris 1974, pp. 18-19). Moreover, Morris has long been a strong advocate of community treatment and apparently does not object to conditioning the terms of probationary or parole release on participation in an appropriate community-based treatment program-at least one "closely and directly" related to the conviction offense (Morris and Hawkins 1970, pp. 112-13, 118-24; Morris 1974, pp. 34, 42-43; Morris and Tonry 1990, pp. 186-203, 206-12).

2. Incapacitation. Morris's second guiding principle, proposed in The Future of Imprisonment, was similarly in conflict with traditional goals and practices of indeterminate sentencing. Morris was opposed to basing prison commitment, duration, and release decisions on individualized assessments of the defendant's degree of "dangerousness" (Morris 1974, pp. 62-73; Morris 1977b, pp. 276-77). Again, Morris argued that we lack the ability accurately to predict future behavior and are very likely to err on the side of massive overprediction and 
overincarceration. The latter excesses occur because of the vague and expansive nature of the notion of "dangerousness." There are also strong political and bureaucratic pressures to err on the side of detention (since "only" criminals are being unnecessarily detained, and their very detention prevents us from knowing which ones would have been safe to release-what Morris calls the "mask of overprediction") (Morris 1974, p. 68). Thus Morris concluded: "Prediction of future criminality is an unjust basis for determining that the convicted criminal should be imprisoned . . or for prolonging its term" (Morris 1974, pp. 59-60, 66).

Morris acknowledged, however, that the fear of crime in general (not just fear of what this particular defendant will do in the future) may help to determine the retributive upper limits of punishment. Such fear might be based on the frequency and distribution of that type of crime, "a few sensational events," "a wave of widely reported crimes," and even the "brutal or mitigating details" of the current offense (Morris 1974, p. 76; see also Morris 1982, pp. 161-62). Morris would also permit parole decisions to be based on actuarial predictions (i.e., "base expectancy rates" of parole success, for various offender categories) (Morris 1977a, p. 148) and would allow "anamnestic" predictions (based on the defendant's past behavior) to influence conditions of parole release (Morris 1974, p. 34). ${ }^{2}$

In later writings, Morris-always the realist-recognized that individualized predictions of dangerousness will be made, whether they are formally permitted or not (Morris 1992, p. 139). He therefore sought to define the narrow conditions under which such predictions might be a fair and effective basis for prison commitment and duration decisions. In particular, he argued that sentencing severity may be increased (up to the retributive maximum) if "reliable actuarial data" indicate that the defendant's risk of assaultive behavior is "substantially" higher than that of other offenders with very similar prior records and current offenses (Morris 1982, pp. 166-72; Morris 1992, pp. 138-47; see also Morris and Miller 1985; and Miller and Morris 1986). However, Morris felt that these conditions would rarely be met. Indeed, it

\footnotetext{
${ }^{2}$ However, Morris favored a fixed duration of parole, rather than the traditional "unexpired term" concept under which the "best risks" (those released earliest) have the longest period of supervision, while the worst risks (those released late, or after "maxing out") have little or no parole aftercare (Morris and Hawkins 1970, pp. 113, 142).
} 
seems likely that they will never be met, since the only "reliable actuarial data" likely to be available would be for groups of offenders with similar prior record and current offense-without distinguishing, as Morris requires, among offenders within each such group.

3. Failure of Prior, Lesser Penalties; Categoric Recidivist Enbancements. In The Future of Imprisonment, Morris argued that increased severity (up to the retributive maximum) is appropriate when "other less restrictive sanctions have been frequently or recently applied to this offender" (Morris 1974, pp. 60, 79-80). Morris seemed to base this provision on retributive grounds-when "lesser sanctions have been appropriately applied and contumaciously ignored . . the criminal law must keep its retributive promises" (Morris 1974, pp. 79-80). ${ }^{3}$ However, such increases in punishment might also be justified on a theory of special deterrence (also sometimes referred to as specific or individual deterrence) (Zimring and Hawkins 1973, pp. 72-74, 224): if the offender did not "get the message" before, increased severity is needed to "get his attention" (or perhaps, to counteract particularly strong temptation). So viewed, special deterrence will sometimes raise the necessary and appropriate penalty above the retributive minimum required.

The imposition of greater severity in such cases might also be justified on grounds of prevention (i.e., incapacitation) of high-risk defendants. Although Morris rejected incarceration based on individualized predictions of dangerousness, he approved of parole release decisions based on actuarial (group, or categoric) predictions of risk. He has also stated that prior convictions are a legitimate reason for sentence enhancement-not only for reasons of desert but also because of the recidivist's statistically greater likelihood of reoffending: "The best predictor of future criminality is past criminality" (Morris 1982, pp. 162-63).

4. General Deterrence. Morris felt that we lack the necessary data to permit general deterrence to serve as a "defining" goal which would precisely calibrate punishment in each case (Morris 1977a, pp. 14042; Morris 1982, pp. 182-83). However, within the retributive upper and lower limits, Morris viewed general deterrence as an appropriate

\footnotetext{
${ }^{3}$ For discussions of various retributive justification for the increased punishment of recidivists, see von Hirsch (1981a); von Hirsch (1985, pp. 77-91); Ashworth (1992, pp. 147-50).
} 
guiding factor. Thus he would permit sentencing severity to be increased (up to the retributive maximum) if such an increase "is necessary to achieve socially justified deterrent purposes, and the punishment of this offender is an appropriate vehicle to this end" (Morris 1974, pp. 60, 79).

In particular, Morris approved of the practice of imposing additional severity "to capture public attention and to deter such behavior by a dramatic punishment"-what Morris calls "exemplary" sentences (Morris 1977a, pp. 151-53; Morris 1982, pp. 187-88). As one example, he cites a British judge's imposition of four-year prison terms (at least double the term normally imposed for the offense) for racially motivated attacks (the Notting Hill cases). Another of his examples is Chicago's annual pre-Christmas crackdown on drunk drivers, designed to counteract the increased incidence of this crime during the holiday period.

Morris would also allow sentences to be mitigated for deterrent purposes-overall, or by some random process of selection-if the crime in question could be controlled effectively by very minor or occasional penalties. His favorite example is federal income tax enforcement (Morris 1974, p. 79), especially for certain, highly risk-averse offenders. Thus of "six Denver doctors" accused of tax fraud, only some need be prosecuted and imprisoned to achieve adequate deterrence (Morris 1977a, pp. 153-56; Morris 1982, pp. 189-92). Given the perennial lack of resources to fully enforce all criminal laws, Morris suggests that selective enforcement and mitigated punishment are a practical necessity; however, for reasons of "parsimony" he would advocate deterrent selectivity even if resources were adequate to permit more frequent and severe punishment (Morris 1977a, pp. 156-58; Morris 1982, pp. 189-90).

5. Equality (or Uniformity). Morris accords the goal of uniformity in sentencing a lower priority than do many just-deserts theorists (and also, perhaps, many supporters of sentencing guidelines). In Morris's view, the goal of equality in punishment is an important consideration in fine-tuning the sentence, "but it is by no means a categorical imperative ... the principle of equality-that like cases should be treated alike-is ... only a guiding principle which will enjoin equality of punishment unless there are other substantial utilitarian reasons to the contrary" (e.g., "exemplary" deterrent enhancement, or "parsimonious" deterrent mitigation) (Morris 1982, pp. 160, 198; see also Morris $1977 a$, pp. 137, 142). Morris acknowledges "the long tradition of jus- 
tice as equality" (Morris 1982, p. 204) and also recognizes that equality is an especially important value in the American context (Morris 1982, p. 180). Nevertheless, he argues that, within the range of "not undeserved" penalties, punishment can be unequal-and even, in some sense, "unfair"-and yet still be "just" (Morris 1977a, pp. 151-63; Morris 1982, pp. 187-92).

Morris points to a number of traditional law enforcement and sentencing practices that are flatly inconsistent with a very restrictive requirement of equality. In particular, he cites the use of selective prosecution, exemplary sentences, and deterrent parsimony; the grant of leniency to defendants who turn state's evidence; the traditional pardon and amnesty powers; and the use of early parole release to avoid prison overcrowding. Morris recognizes that equality values are traditionally viewed as strongest at the point of sentencing and are weaker both in the earlier, police- and prosecutor-controlled stages and in the later correctional processes. Nevertheless, he believes that, in light of such substantial (and, perhaps, inevitable) systemwide inequality, the sentencing process cannot, and should not, attempt to observe strict equality constraints (Morris 1982, pp. 206-8). This conclusion also follows from his strong belief in the concept of "parsimony," which "overcomes the principle of equality" (Morris 1977a, p. 154; Morris 1982, p. 191).

6. Parsimony. In The Future of Imprisonment, Morris argued that one of the most important guiding principles of sentencing is that "[t] he least restrictive (punitive) sanction necessary to achieve defined social purposes should be imposed" (Morris 1974, p. 59). Morris found direct support for this principle in the American Bar Association's Sentencing Standards (American Bar Association 1968, $\$ 2.2)^{4}$ and implicit support in recent National Crime Commission proposals and in the Model Penal Code's general presumption in favor of probation (American Law Institute $1962, \S 7.01)$. He further argued that important analogues of the principle can be found in cases interpreting the prohibition of cruel and unusual punishments (since "any punitive suffering beyond societal needs is what, in this context, defines cruelty") and in mental health and juvenile justice dispositional standards (Morris 1974, pp. 60-62).

For Morris, the principle of parsimony "is both utilitarian and hu-

\footnotetext{
${ }^{4}$ The principle is also found in the second and third editions of these standards (American Bar Association 1979, $\$ 18-2.2$; American Bar Association 1993, $\$ 18-2.4$ and 18-6.1).
} 
manitarian" (Morris 1974, p. 61). The concept has long been a central tenet of utilitarian philosophy. As Michael Tonry points out, writers at least as far back as Jeremy Bentham (1789) argued that "punishment itself is an evil and should be used as sparingly as possible ... 'it ought only to be admitted in as far as it promises to exclude some greater evil'" (Tonry 1994, p. 63, quoting Bentham). Parsimony is also perhaps a necessary (or at least a natural) corollary of a theory of limiting retributivism; if judges are permitted broad rather than narrow ranges of "just" punishment, some overarching principle such as parsimony is needed to give them more guidance, or at least a more precise "starting point."

Broader sentencing ranges, combined with the principle of parsimony, permit and encourage the exercise of mercy. As Morris eloquently put it, "justice and mercy both have roles in the criminal justice system; mercy cannot be precisely quantified and institutionalized or it ceases to be mercy and becomes leniency; mercy is the trump that can capture equality's ace and allow punishment at the bottom range of a deserved punishment" (Morris 1982, p. 180). Parsimony in the use of custodial sentences also permits the preservation of the defendant's social ties (Morris 1974, pp. 8, 75) and the avoidance of needless suffering and expense (Morris 1977a, p. 154). In any event, Morris argued, the ability to grant case-level mitigation of punishment, without strict desert or equality constraints, is a necessary and inevitable feature of our chronically overloaded and underfunded criminal justice system (Morris 1977a, pp. 156-58; Morris 1982, p. 190).

To summarize, Morris believed that judges should use the lower end of the range of "deserved" punishments as a starting point and should increase that penalty only if (and only to the extent that) one or more of his other "guiding" factors requires increased severity in the particular case. Thus the specific sentence would be determined by whichever factor required the greatest severity (general deterrence, failure of prior lesser penalties, and [very rarely] actuarially based predictions of dangerousness).

Case-specific ("individual") desert considerations are also relevant. Morris would probably say that case-specific desert imposes strict upper limits on punishment (i.e., that it lowers the maximum severity that may be imposed for utilitarian reasons). However, given his general view that lower desert limits are more flexible, he might argue that only cases of exceptionally aggravated culpability should serve to raise 
the judge's "starting point" (i.e., the minimum of the statutory or guidelines range), before consideration of utilitarian goals.

It is not clear exactly how Morris's guiding principle of equality is reconciled with the principle of parsimony, since the two will often be in conflict. However, if the presumption in favor of the least severe sentence is a strong presumption, and if judges thus usually sentence near the bottom of the "not-undeserved" range, then sentences will tend to be fairly uniform among offenders whose cases fall into the same range. Morris probably did expect that sentences would cluster near the bottom of the desert range-if only for lack of sufficient utilitarian justification for raising them higher; he has often argued that criminal laws and punishments have very little effect on crime rates (Morris 19776, pp. 267-69; Morris 1993, p. 309).

7. Rewarding Defendant Cooperation (Especially Guilty Pleas). As everyone familiar with American criminal courts knows, the most important "guiding" factor in sentencing is often the defendant's plea. Morris expressed dislike for the exchange of "concessions" for guilty pleas (Morris 1974, p. 52) and the resulting coercion, overcharging, and distortion of the sentencing process (Morris 1977a, p. 147; Morris and Hawkins 1977, pp. 57-58). But Morris is a realist and recognizes the practical reasons that underlie the grant of leniency to defendants who "cooperate." His proposed alternative to traditional plea bargaining is a pretrial "settlement" conference, attended by the judge, prosecutor, defense attorney, defendant, and victim (Morris 1974, pp. 50-57; see also Heinz and Kerstetter 1979, passim, reporting on the successful implementation of Morris's proposal in Dade County, Florida). This procedure is intended to better regulate the process; however, it appears to assume considerable flexibility in sentencing and does not rule out charge and/or sentence mitigations resulting from the conference.

For similar practical reasons, Morris recognized the need to grant good-conduct ("good-time") reductions of prison terms to encourage cooperation and maintain order (Morris 1974, p. 49; Morris 1977b, p. 277). He also appeared to approve of the occasional grant of even earlier release, where necessary to avoid or lessen serious prison overcrowding problems (Morris 1982, p. 189).

It is not clear how the cooperation mitigations noted above should be incorporated into Morris's desert-range-with-parsimony theory. If such mitigations are not to undercut essential (nothing-less-will-do) crime control measures, it would seem necessary to initially add some 
additional severity (within desert limits) to what the latter measures minimally require, in order to leave room for cooperation-rewarding mitigations. For example, prison terms would need to be increased by the maximum good-time credits prisoners may earn.

\section{Morris on Sentencing Guidelines}

Morris opposed legislatively drafted determinate sentencing reforms, when they were first proposed and enacted in the mid-1970s (Morris 1977a, pp. 149, 164; Morris 1977b, pp. 272-81). He recognized (as he had since 1951) that sentencing disparity is a serious problem but felt that the solution was not to impose excessive legislative rigidity; the necessary "fine-tuning" of the sentence must be done by the trial court (Morris 1977b, pp. 272-75). Thus he preferred to continue on the path of criminal law reform (recodification; statutory guiding principles) inspired by the Model Penal Code (Morris 1977b, pp. 275-76). At the same time, Morris strongly advocated two reforms which subsequently became essential features of most sentencing guidelines systems: the requirement that trial judges state reasons for their sentences and appellate review of sentences (Morris 1977a, pp. 149-50, 164-65; Morris 1977b, pp. 275-76; Morris and Hawkins 1977, pp. 59-60). Morris hoped that these reforms would facilitate the gradual evolution of binding precedents on frequently occurring issues-what he termed a "common law of sentencing."

Morris gave qualified support to the earliest federal bills calling for the creation of a sentencing commission to promulgate guidelinesprovided that such guidelines retained sufficient judicial discretion (Morris 1977a, pp. 149-50, 165; Morris 1977b, pp. 276, 281-85). His support was due in part to the fact that these bills included requirements of trial court reasons and appellate review. However, Morris may also have recognized the value of having an independent commission make case-level sentencing policy. In The Future of Imprisonment, Morris had identified an important "latent" function of the parole board: the precise timing of prison release could be determined at a time and place removed from the "emotional intensity" and the "searchlight of public attention" that often attends the trial and initial (maximum) sentence determination (Morris 1974, pp. 36-37, 39, 48). Later, in Madness and the Criminal Law, Morris noted a similar problem with legislative control over case-level sentencing severity: political pressures to be "tough on crime" inevitably cause legislators to set penalties based on the "worst" case of each type (Morris 1982, p. 158). 
Thus if parole-release discretion were to be eliminated, under sentencing guidelines, ${ }^{5}$ and prisoners were then expected to serve most of the sentence imposed by the court, the shorter (but "real-time") presumptive sentences must be set by a body independent of the legislature. This "insulation" argument subsequently became, and remains, one of the major justifications for commission-based sentencing guidelines (Frase 1991a, pp. 729-30).

In his later writings, Morris gave much stronger support to the new (commission-based) sentencing guidelines movement (Morris 1982, pp. 172-76; Morris and Tonry 1990, pp. 48-49; Morris 1993, p. 307, 309). Nevertheless, he has criticized state and federal guidelines for putting too much emphasis on prison sentences, without enough attention to the wide variety of "intermediate" sanctions more restrictive than straight probation (Morris and Tonry 1990, pp. 37-42; Morris 1993, pp. 307-8, 310).

In his book written with Michael Tonry, Between Prison and Probation, Morris proposed to replace the "two-zone" systems found in most state guidelines grids (presumed prison; presumed probation) with a system employing multiple presumptions and multiple sanction types (Morris and Tonry 1990, chap. 3). For example, he expressed strong support for the "four-zone" system proposed by the District of Columbia Sentencing Guidelines Commission: the least serious group of offenders receive only community-based sanctions (e.g., probation, fine, restitution, and/or community service); cases in the second, more serious, group may receive either a community sentence or custody, with a rebuttable presumption in favor of the former; for the third group, judges would have the same choices, but without the presumption; in the most serious cases, a custodial sentence was specified (Morris and Tonry 1990, pp. 60, 77).

To further guide judges, and encourage the use of noncustodial sanctions, Morris and Tonry proposed the development of a system of "interchangeable" punishments (Morris and Tonry 1990, pp. 75-81, 90-92). Judges would first decide the primary purposes to be served by that offender's sentence; the judge would then select a package of

\footnotetext{
${ }^{5}$ Except for the latent function noted in text, Morris was quite willing to abolish parole release discretion. He felt that such discretion could not be justified by the need to make individualized assessments of reform and/or dangerousness (which he rejected) and was not needed to maintain prison discipline, maximize deterrence, avoid prison overcrowding, or rectify unjust disparities; each of the latter functions could be better served by other means (or were not being effectively served by parole discretion in any case) (Morris 1977b, pp. 276-79).
} 
sanctions designed to achieve those purposes (and no more severe than necessary to do so) (Morris and Tonry 1990, pp. 90-92). Similarly situated offenders (i.e., those with similar conviction offense and prior record) would receive sanction combinations roughly equal in their overall punitiveness. This would be achieved by means of "equivalency scales," defining the relative severity of different sanction types (Morris and Tonry 1990, pp. 92-108)—for example, two months of home detention equals one month of imprisonment.

Very serious cases were excluded from the proposal above, for both theoretical and practical reasons (Morris and Tonry 1990, pp. 78-79, 123). In such cases, any sentence other than prison would depreciate the seriousness of the offense (thus violating Morris's retributive minimum); also, such offenders are likely to be violent, and thus in need of custodial restraint. As a practical matter, it is difficult to enforce community-based sanctions equivalent in severity to very long prison terms (Morris and Tonry 1990, p. 173). At the other end of the severity spectrum, "trifling" cases were also excluded (Morris and Tonry 1990, p. 79) - presumably because principles of parsimony call for nothing more severe than straight probation.

\section{Summary}

Morris's theory of punishment is both principled and pragmatic. Some features are based on strong normative arguments. However, as foreshadowed in his first book, he has also very deliberately tried to fashion a theory that is congruent with the widely held values and practices of judges and other system actors. In opting for a hybrid theory, seeking to balance conflicting punishment goals, case-specific factors, and practical realities, Morris recognized (quoting H. L. A. Hart) that "the pursuit of one aim may be qualified by the pursuit of others"; in the end, he concluded, "there is no universal formula ... penal policy always represents a choice among a plurality of aims and objectives and every decision we reach may be attended by some disadvantages" (Morris and Hawkins 1970, p. 123).

II. Von Hirsch's Critique, and Morris's Response Von Hirsch is probably the best-known American advocate of the "just-deserts" model of sentencing (von Hirsch 1976, 1981a, 1981b, 1985, 1992, 1993), and he has frequently criticized Morris's theory of punishment. In this section, I outline the general principles of von Hirsch's own theory, summarize his major objections to Morris's 
views, and consider the responses that Morris has made, or which could be made, to these criticisms.

\section{A. Summary of von Hirsch's Sentencing Theory}

In Morris's terms, von Hirsch is a "defining" retributivist: desert and equality goals define, within narrow limits, the precise degree of punishment severity which each offender must receive, relative to other offenders. Von Hirsch believes that the criminal law is primarily and essentially a "blaming" institution and that criminal penalties properly convey "censure" to the offender as well as the public (von Hirsch 1976, chap. 8; von Hirsch 1985, chap. 3; von Hirsch 1993, passim). Such expressions of blame serve to recognize the importance of the individual and societal rights violated by the offense and also confirm the offender's responsibility by addressing him or her as a responsible moral agent, capable of understanding right and wrong (von Hirsch 1992, p. 67). In such a system, the relative severity of sanctions imposed on different offenders must be closely correlated with the relative blameworthiness of these offenders (the requirement of "ordinal proportionality"), and equally culpable offenders must receive equally severe sanctions (the requirement of "parity") (von Hirsch 1985, p. 40; von Hirsch 1992, p. 79).

The concept of "ordinal" proportionality deals with issues of relative severity - the rank order and spacing of severity increments of penalties, for offenses of increasing seriousness. Von Hirsch distinguishes sharply between ordinal proportionality and "cardinal proportionality"-the determination of absolute degrees and types of severity (von Hirsch 1985, pp. 39-40; von Hirsch 1992, pp. 83-84). For von Hirsch, there are at least two important issues of cardinal proportionality which must be addressed in any punishment system: the definition of the upper and lower extremes ("anchoring points") of the punishment scale (e.g., death, and/or the maximum prison term; suspended sentence, or other least severe authorized penalty) (von Hirsch 1985, pp. 92-94; 1992, pp. 75-79, 83-85); and the exact placement of lines dividing different zones or types of punishment (e.g., the point at which incarceration is the appropriate disposition rather than some relatively severe noncustodial penalty) (von Hirsch 1981b, pp. 787-89). ${ }^{6}$

${ }^{6} \mathrm{~A}$ third issue is treated by von Hirsch in a manner somewhat similar to questions of cardinal desert. That issue is whether "hard treatment" such as prison is the required means with which to express censure or whether more symbolic, verbal denunciation is sufficient. Von Hirsch believes that this choice is not determined by the logic of desert 
Von Hirsch views the requirements of cardinal desert as much less constraining than those of ordinal desert. Like Morris's view of desert generally, von Hirsch feels it is difficult to say exactly what absolute degree or type of severity each offender deserves; but we can at least say that some penalty scales are clearly too severe or too lenient in the type or degree of sanctions (von Hirsch 1985, pp. 43-46). Given this greater degree of uncertainty, von Hirsch would allow the legislature or sentencing commission to consider nonretributive goals-including crime control, parsimony, and available resources-when deciding issues of cardinal proportionality (von Hirsch 1985, p. 45; von Hirsch 1987b, pp. 94-95; von Hirsch 1992, pp. 83-84). But he would rarely allow either crime-control or parsimony goals to affect the ordinal proportionality decisions made by the legislature or sentencing commission, nor would he allow such goals to be considered by judges on a case-specific basis (von Hirsch 1985, pp. 40-46).

\section{B. Von Hirsch's Critique of Morris's Theory}

Von Hirsch finds Morris's sentencing theory vague, unfair, and likely to produce unduly severe results (von Hirsch 1981b, pp. 772-89; von Hirsch 1984, pp. 1094-1110; von Hirsch 1985, pp. 38-46, 13946; von Hirsch 1992, pp. 89-90; von Hirsch 1993, pp. 64-68). ${ }^{7}$ His specific questions and criticisms are summarized below.

Just how broad are the desert ranges, he asks-except for very serious offenses, would anything from a suspended sentence to the statutory maximum prison term be permitted? Does desert "substantially constrain" the sentence, or is it "relegated to the margins?" (von Hirsch 1981b, p. 785). Furthermore, how are these ranges set? What specific factors should legislators or guidelines commission members consider, in setting anchoring points or range widths? How are courts supposed to apply Morris's numerous but conflicting "guiding principles," to determine the precise sentence within the range?

Von Hirsch also questions the precise meaning of "mercy," which Morris says his broader ranges permit. Von Hirsch believes that this concept may be closely related to "desert"; if so, he argues, it does not operate within desert limits but rather serves to define the truly deserved sentence (von Hirsch 1984, pp. 1107-8).

and (like the two "cardinal" desert issues noted in text) depends instead on crimeprevention needs (von Hirsch 1992, pp. 73-74).

' See also von Hirsch (1994, pp. 39-49) and von Hirsch (1995, pp. 160-61, 163-64, n. 32), criticizing this author's previous writings defending Morris's limiting retributive theory, as adopted in Minnesota. 
Similarly, what is "parsimony"? If this is simply the traditional utilitarian goal of maximizing efficiency (no more expense, pain, or other "cost" than is necessary to achieve all legitimate utilitarian purposes), then it is a consequence of pursuing utilitarian goals, not a justification for choosing or preferring such goals. Although admitting that Morris himself avoids such circular reasoning, von Hirsch notes that other advocates of parsimony have not (von Hirsch 1984, p. 1107).

Von Hirsch also faults Morris for using current or past sentencing practices (e.g., the imposition of exemplary sentences) to argue for his theory: "Citing the existence of a sentencing practice does not demonstrate the justice of that practice" (von Hirsch 1984, p. 1104; emphasis in original).

Von Hirsch and Morris are in fundamental disagreement on the meaning of "justice" and "fairness." In von Hirsch's view, Morris's limiting retributive theory would allow routine imposition of unequal penalties on equally culpable offenders and would even permit less severe punishment to be given to more culpable offenders (von Hirsch 1984, pp. 1102-3; von Hirsch 1992, p. 76; von Hirsch 1994, p. 45; von Hirsch 1995, pp. 163-64, n. 32). This is simply too unfair, and it violates the basic premises of criminal law as a "blaming" institution. Von Hirsch is also critical of Morris's willingness to give prior convictions a significant role in defining the outer limits of desert; in von Hirsch's view, the proper role of criminal history is quite modest (von Hirsch 1985, pp. 77-91; von Hirsch 1994, pp. 39-40).

Finally, von Hirsch questions whether application of a limiting retributive theory, even one which included Morris's principle of parsimony, would promote lower, more reasonable degrees of sentencing severity (von Hirsch 1984, pp. 1104-7; von Hirsch 1985, pp. 140-46; von Hirsch 1993, pp. 67-68; von Hirsch 1994, pp. 43-46). Von Hirsch appears to agree with Morris that sentencing severity, and especially the use of incarceration, is excessive in the United States. However, von Hirsch believes that sufficient leniency can be achieved without sacrificing ordinal proportionality and parity, by simply lowering the upper and lower anchoring points of the punishment scale and encouraging judges to forgo custodial penalties in favor of noncustodial, intermediate sanctions of approximately equal severity (von Hirsch, Wasik, and Greene 1989, pp. 599, 604-6; von Hirsch 1992, pp. 80, 92-93).

Von Hirsch feels that giving judges a broad sentencing range may actually invite excessive punishment, not parsimony--judges may 
choose sentences closer to the maximum end, and legislators or sentencing commissioners may feel freer to increase these maxima than they would under a more "defining" desert scheme. In any case, lowering sentences for some offenders almost inevitably means raising them for others. "Parsimony for whom?" von Hirsch asks; the offenders receiving increased punishment will not appreciate the parsimony extended to others (von Hirsch 1984, pp. 1106-7; emphasis in original).

\section{Morris's Response to von Hirscb's Criticisms}

Morris has not written a comprehensive rejoinder to von Hirsch's criticisms, although he has responded specifically to some of them (Morris 1982, pp. 202-5; Morris and Tonry 1990, pp. 84-90). The summary below is based on the latter responses; on arguments Morris has indirectly aimed, over the years, at von Hirsch's theory; and on my assessment, based on all of Morris's work, of the additional arguments Morris could make to round out his reply.

On the initial question of range width, and the relative importance of desert and nondesert goals, Morris agrees that the very "modest" role of desert, under the American Bar Association's second edition of its sentencing standards (American Bar Association 1979), goes too far; Morris favors stronger desert constraints, in "an ordered system of justly deserved punishments" (Morris 1982, p. 203). In his later writings, Morris gave strong support to sentencing guidelines, particularly the Minnesota version. This implies that his suggested ranges are comparable in width to the cells on the Minnesota guidelines grid. At one point, in discussing how a sentencing commission might set presumptive terms for second-offense purse snatchers, Morris suggested that a range running from probation to six-months' custody would be appropriate (Morris 1982, pp. 194-96). ${ }^{8}$

Von Hirsch finds Morris's praise of the Minnesota guidelines curious, since he feels that these guidelines "come close to adopting the desert parity that Morris wishes to reject" (von Hirsch 1984, p. 1100, n. 29). To this, Morris might reply (having read Sec. III below), that the Minnesota guidelines do not, in fact, give "desert parity" nearly as big a role as von Hirsch claims. He would also point out that even von Hirsch allows some flexibility in the application of his ordinal proportionality principle: sanctions for equally culpable offenders need only

\footnotetext{
${ }^{8}$ See also Morris and Tonry (1990), p. 90 (of three like-situated offenders, one might appropriately receive a six-month prison term; the second, a substantial fine; and the third, required participation in a drug treatment program).
} 
be "approximately" equivalent in severity (von Hirsch 1992, pp. 80, 92-93), and the gradations (spacing) of penalties for crimes of increasing severity "are likely to be matters of inexact judgment" (von Hirsch 1992, p. 83).

As to the method by which desert ranges would be defined, Morris implies that this is ultimately a political decision, which could be made in a variety of ways, including public or judicial surveys and legislative or sentencing commission deliberation and consensus building (Morris and Tonry 1990, p. 85). It would also seem that Morris (or the sentencing commission) could employ von Hirsch's own methods of ordinal ranking and spacing to produce one series of proportioned upper limits (Tonry 1994, p. 80), tied to appropriate desert-based categories of conviction offense and prior record, and a second series of proportioned lower limits (at least for those offenses deemed serious enough to require minimum desert standards). Finally, as previously discussed, Morris's theory does provide considerable guidance to judges in picking the precise sentence within the outer limits of desert: judges should start at the bottom of the range and increase severity only to the extent needed to meet all appropriate utilitarian and case-specific desert needs.

On the meaning and importance of "mercy," Morris might agree that this is sometimes related to desert (and he agrees that such casespecific desert factors have a role to play in fine-tuning the sentence). However, Morris would also say that von Hirsch leaves insufficient room for appropriate exercise of case-level mercy that is unrelated to desert-for example, the traditional pardon and amnesty power, and the grant of early release to relieve prison overcrowding. Another example of undeserved mercy, discussed by Morris, is the parable of the prodigal son (Morris 1982, pp. 205-6). Morris argued that there are useful sentencing analogies to the theological issues of repentance, forgiveness, and divine mercy illustrated by the parable. The theme of forgiveness is also emphasized in Morris's proposal to include the victim in a pretrial settlement conference (Morris 1974, pp. 56-57). In retrospect, it seems that Morris anticipated the development of the theory of restorative justice, which emphasizes the importance of defendant acceptance of responsibility, victim forgiveness, and victimoffender reconciliation (Cragg 1992, passim, but esp. pp. 204-17).

Morris would also argue that judges must have broad discretion to mitigate sentencing severity if (as von Hirsch himself advocates) courts are to make greater use of intermediate sanctions. As a practical mat- 
ter, any theory requiring rigid "equality of suffering" among offenders with similar offense and prior record precludes frequent substitution of noncustodial sanctions-for example, lengthy community service obligations are difficult to enforce (Morris and Tonry 1990, pp. 168$69,173)$. A rigid theory of equality and desert thus forces judges to impose needless and expensive incarceration that serves no social good other than to provide symbolic denunciation (and, perhaps, "miseryloves-company" satisfaction). As discussed more fully below, Morris gives little weight to the latter grounds. In his more recent writings, von Hirsch seems to agree that relaxing desert constraints would facilitate substitution of noncustodial penalties (von Hirsch 1992, pp. 9293). However, he appears unwilling to accept any major departures from his central principles of parity and ordinal desert.

As for von Hirsch's point that the existence of a practice does not necessarily prove its validity, Morris would almost certainly agree. However, he might counter that the existence of a widespread practice often says something about our basic moral and societal values, which is why philosophers (including von Hirsch himself; von Hirsch 1981a, pp. 595-613) traditionally have cited everyday concepts and practices to illustrate fundamental moral principles. Morris would also point out that the abstract justice or logic of a theory does not guarantee that judges and other practitioners will accept it in practice. Morris recognized that these system actors are strongly committed to pursuing a variety of sentencing goals and will never accept a pure, one-dimensional retributive theory (Morris and Tonry 1990, pp. 87-88). If such a theory were forced on them, they would use their remaining, unregulated discretionary powers to undercut it (Morris 1982, p. 158; Morris 1992, p. 139).

Morris also questions the internal logic and persuasiveness of von Hirsch's theory. Von Hirsch concedes that "cardinal" desert is difficult to precisely define; Morris questions whether "ordinal" desert is really so different. For Morris, "judgments of comparable [i.e, ordinal] culpability are enormously difficult to make," given the imprecision of offense categories and criminal history records, the ambiguities of social deprivation, and other factual and moral uncertainties (Morris and Tonry 1990, p. 87). How-other than by simply assuming it-can von Hirsch be so sure that ordinal ranking and spacing decisions permit a high degree of societal consensus and precision as to desert? And how can he categorically rule out any consideration of nondesert factors, in making ordinal decisions? 
Indeed, is the cardinal/ordinal distinction even that clear? Von Hirsch considers a guidelines commission's decision about where to draw the "in/out" line (presumptive prison/presumptive probation) to be an example of cardinal (absolute) desert, thus permitting much greater flexibility and the consideration of nondesert factors. But in practice, the imposition of a prison sentence often results in a major "step-up," at least in symbolic denunciation (and often also in actual severity), when compared to the most severe nonprison sanction. Thus wherever the in/out line is drawn, it is likely to violate von Hirsch's requirements for precise ordinal spacing-increased severity directly proportional to increased blame.

Morris might also question von Hirsch's assumption that the sentencing process is a "blaming" or "censuring" institution (and therefore by its very nature, must impose penalties conforming to strict standards of ordinal desert). This essential premise seems somewhat at odds with von Hirsch's view that "cardinal" issues may be strongly influenced by crime-control purposes. Decisions on cardinal issuesthe absolute severity and the form of punishments-determine the basic parameters of any system of criminal sanctions; if such fundamental issues are closely linked to utilitarian concerns, how can von Hirsch insist that punishment is still "essentially" or "primarily" a blaming institution?

Morris further questions von Hirsch's arguments based on "fairness." Morris freely admits that his theory allows equally blameworthy defendants to receive unequal degrees of severity and thus permits the more blameworthy to receive less punishment. This much is implicit in any system of broad, overlapping desert ranges (although Morris's examples of overlapping ranges are for offenses of fairly similar severity-murder and manslaughter; rape and aggravated assault; Morris 1982, p. 151). But such "failures" of ordinal proportionality are not necessarily either substantial in degree or routine, as von Hirsch asserts. Morris's principle of parsimony, combined with his recognition of equality as an important guiding factor, are intended to result in most defendants receiving punishment near the bottom of their desert range; thus most sentences will be roughly proportionate to (ordinal) desert.

More fundamentally, however, Morris questions von Hirsch's assumption that equality values trump all other concerns. Although equality is an important goal of sentencing, few people believe it is the only goal (Morris and Tonry 1990, pp. 86-87, 89). As discussed more 
fully in Section III below, Morris's assumptions about popular notions of equality and "fairness" seem to be borne out, at least in Minnesota; the people of that state have, for over fifteen years, accepted a guidelines sentencing system with much greater departures from ordinal desert than von Hirsch would allow. Different sentences for two offenders of equal blame are apparently seen as "fair," provided there are good (nondesert) reasons for unequal treatment, and provided further that the differences are not too great, or too often linked to $b a d$ reasons (e.g., racial bias).

The latter problem is, of course, a very legitimate concern. Although von Hirsch has not specifically accused Morris of promoting or tolerating invidious distinctions, Morris himself recognizes that a broader sentencing range, with discretion to be selectively lenient, risks allowing distinctions to be made along race and class lines. But he argues that if discretion is denied, to minimize the potential for bias, the alternative in practice will often simply be to impose uniformly severe penalties on all offenders, with no evidence that society or anyone else is benefited (Morris 1982, pp. 158-59).

Morris could also easily defend his conception of desert, as allowing substantial weight to be given to the defendant's criminal record. $\mathrm{He}$ notes that criminal history is "the second most significant factor in defining the amount of punishment in all existing systems of criminal punishment" and has a legitimate role for reasons of both crime control and desert (Morris 1982, pp. 162-63); it thus should be, and will always be, a major factor. Other retributive theorists have also been willing to give criminal history a greater role than does von Hirsch (Bottoms 1995, p. 22, n. 17, citing Andrew Ashworth 1992).

Finally, Morris disagrees that sufficient parsimony can be provided simply by lowering the anchoring points on the punishment scale. Given the political pressures they face, legislators are very unlikely to do this (Morris 1982, pp. 157-58), and beyond a certain point, neither is an independent (but politically appointed) sentencing commission. Thus power to grant case-level leniency, without strict desert and equality constraints, is essential. Such power is particularly critical if, as so often happens, the legislature also fails to provide enough prison space and other resources to accommodate the scale it has enacted. Moreover, case-level mitigations will continue to be granted by prosecutors through their charging and plea-bargaining discretion, evenindeed, especially_if such power is denied to judges (Morris 1982, p. 
158). Morris feels that this power is better shared with judges and brought out in the open; if dealt with openly and honestly, principles can be developed to provide guidance, and judges can be encouraged to state reasons for their decisions. Morris has long been a foe of hypocrisy and secrecy and prefers an open and honest approach. As he once said, in arguing to decriminalize "victimless" crimes, "what is required is better regulation ... it is impossible to regulate behavior that is probibited" (Morris and Hawkins 1977, p. 21; emphasis in original).

Another defect of von Hirsch's approach is that, given his strict "ordinal proportionality" requirements-including proportional spacing of penalties-it is impossible for the legislature or sentencing commission to lower penalties for less serious offenses (e.g., to stay within available resources) without also lowering penalties for more serious offenses; simply lowering the "low" end of the grid would change the spacing, thus violating ordinal proportionality (or at least, whatever proportionality assessments underlay the original grid). Similarly, sentences could not be raised for violent offenders, without raising the entire penalty scale. Yet sentencing systems need to be able to respond to major changes in the type or volume of crime and to give priority, in the allocation of scarce resources, to more serious crimes. States should not have to raise or lower the entire penalty scale to respond to these needs. Von Hirsch would probably view such constraints as a "plus," assuming that the legislature, reluctant to raise the entire scale, would keep all penalties low and "parsimonious." Morris would reply that a far more likely scenario is to raise all penalties, with the expectation of massive (but selective and inconsistent) mitigation of sanctions for less serious offenders.

Morris would also insist that his theory would not, as von Hirsch claims, lead to greater sentencing severity. Judges could not routinely sentence close to the maximum of desert without violating Morris's central principle of parsimony. Legislatures could, of course, unwisely raise the maximum and/or minimum desert-range limits, just as they could raise von Hirsch's cardinal "anchoring points." Whether they would feel freer to do this in a system of broad ranges is speculative, and cannot be answered in the abstract, for all jurisdictions (see Sec. III below). It should also be recognized that if only the range maximums were raised, judges would remain free (and, under the parsimony principle, would be expected) to continue to sentence most cases near the bottom end of the desert range. 


\section{Summary}

Von Hirsch and Morris appear to agree on several important points: first, that the concept of desert is very important; second, that the preguidelines systems of "indeterminate sentencing" gave far too great a role to offender-based rehabilitative and incapacitative goals; and third, that parsimony is important-sentencing severity, and especially the use of incarceration, are excessive in the United States.

However, von Hirsch and Morris disagree strongly on the details of a system of desert-oriented sentences, designed to limit unjustified disparity and promote parsimony. As frequently happens in such debates, the two writers often talk past each other because of their fundamentally different assumptions (Tonry 1994, pp. 77-79). Morris values, and wants to accommodate, a much broader range of sentencing goals, and he is also very concerned with how well his proposed principles will be accepted (and consistently applied) in practice. Von Hirsch is striving to create a logical and coherent sentencing theory, without much regard for either the value of nondesert goals or how well his theory accords with traditional practices. These two authors also seem to have very different ideas of what is intuitively "fair." Of the two, Morris would seem to be more attuned to what people actually think is fair, at least in Minnesota.

\section{The Minnesota Sentencing Guidelines, in Theory and Practice ${ }^{9}$}

The Minnesota Sentencing Guidelines Commission adopted retribution (just deserts) as its primary sentencing goal (Minnesota Sentencing Guidelines Commission 1980, p. 9; Minnesota Sentencing Guidelines Commission 1984, pp. v, 10-14). However, the original 1980 version of the guidelines also gave substantial emphasis to utilitarian goals, which had strong legislative support. The role of nonretributive purposes has grown in the fifteen years since the guidelines became effective, but the changes have been gradual, and usually built on themes that were clearly present in the original guidelines and enabling legislation. Just deserts continues to play a very important role in Minnesota sentencing, but its role is more accurately described as a "limiting" one: defining the maximum sentence severity in almost all cases and, for the most serious cases (about one-fifth of the annual caseload), specifying relatively flexible standards of minimum severity.

\footnotetext{
${ }^{9}$ An earlier version of this section of the article appeared in Frase (1994).
} 
In this section of the essay, I first examine the Minnesota legislature's original intent regarding sentencing goals. I then present a brief summary of how the guidelines work, describe how the Minnesota Sentencing Guidelines Commission carried out its statutory mandate, and analyze the commission's original intent (including what it did, as well as what it said it was doing). Finally, I discuss how punishment theory under the guidelines has evolved over time, addressing the sentencing purposes implicit in appellate case law interpreting the guidelines, significant legislative and commission actions since 1980, and the actual sentencing practices of trial judges and attorneys.

\section{A. The Original Legislative Intent}

The 1978 guidelines enabling statute (1978 Minn. Laws, chap. 723) contained no explicit statement of sentencing theory and imposed relatively few specific mandates. The Minnesota legislature simply directed the newly created commission to promulgate guidelines (regulating both the decision to impose state imprisonment and the duration of such imprisonment), based on "reasonable offense and offender characteristics," while taking into "substantial consideration" two factors: "current sentencing and releasing practices" and "correctional resources, including but not limited to the capacities of local and state correctional facilities." The commission was also permitted (but was not required) to develop guidelines regulating the conditions of nonprison sentences.

The enabling statute abolished parole release discretion and substituted a limited reduction (up to one-third off the pronounced sentence) for good behavior in prison. This earned good-time reduction then constitutes a period of parole-type postrelease supervision (the supervised release term). The statute also implied that denial of goodtime reductions could only be based on disciplinary violations, not failure to participate in or cooperate with in-prison treatment programs (since all such programs were to become voluntary).$^{10}$ Finally, the statute requires sentencing judges to provide written reasons when they depart from the guidelines, and both defendants and the prosecution are given the right to appeal any sentence (whether or not it is a departure).

It seems clear that a major purpose of the statute was to reduce sen-

${ }^{10}$ Since 1993 , inmates may lose good-time credits if they refuse to work or participate in treatment programs. See Sec. IIIIC2 below. 
tencing discretion, thus promoting greater uniformity of sentences, but what broader purposes did the legislature want such sentences to serve? Did it intend to move toward a "just-deserts" model, with sharply reduced emphasis on rehabilitation, incapacitation, and deterrence? The legislative preference for greater uniformity does not, by itself, imply a strong emphasis on retributive values: reduced case-level discretion limits the ability of courts to "fine-tune" their assessments not only of each offender's treatment needs and dangerousness but also of his or her precise deserts (Frase 1991b, p. 332).

Von Hirsch has argued that the Minnesota enabling statute "suggests no particular rationale" or choice between sentencing purposes (von Hirsch 1987a, p. 65). However, on closer inspection it appears that the legislature did take a position, albeit an imprecise one (Frase 1993b, pp. 347-49). First, the legislature left unchanged several references to utilitarian goals and offender-based sentencing, contained in the state's criminal code. Second, the enabling statute directed the guidelines commission to give "substantial consideration" to existing sentencing and releasing practices, which suggests limited change in preexisting norms and therefore substantial continued emphasis on the utilitarian goals which had dominated preguidelines sentencing.

Of course, the statute did limit the pursuit of utilitarian goals (especially rehabilitation and incapacitation) in several ways: discretionary parole release was abolished, and all prison treatment programs were made voluntary. But the statute did not forbid consideration of the offender's treatment needs or dangerousness when determining whether to impose a prison term, nor did it preclude the imposition of conditions of probation or supervised release designed to promote rehabilitation or public safety. Thus although individualized parole-risk assessments and coerced "cure" in prison were both abandoned, probationrisk assessments and required treatment in the community were not necessarily rejected. ${ }^{11}$

Nor does the legislative history of the enabling statute evince an intent to emphasize retribution, abandon utilitarian goals, or dramatically change any existing sentencing norms. The 1978 act was the culmination of several years of legislative ferment over the sentencing reform issue, reflecting increasing dissatisfaction with indeterminate sentencing, but disagreement over what to do about it (Parent 1988,

\footnotetext{
"Goodstein (1983), p. 494, noting the early emergence of the practice of setting mandatory treatment conditions of supervised release (the Minnesota guidelines "parole" term).
} 
pp. 21-27; Frase 1993b, pp. 347-49). Sentencing purposes were rarely debated as such; whatever consensus there was at that time seemed to focus on abolishing the parole board and increasing the uniformity of sentences, while at the same time avoiding any overall increase in sentencing severity and prison populations.

It thus appears that the most probable legislative purposes in enacting the 1978 enabling statute were, first, to sharply limit judicial and parole discretion in the pursuit of all of the traditional purposes of punishment, without abandoning any of those purposes, or strongly preferring some over others; second, to emphasize that state prison sentences are imposed primarily to achieve retribution, deterrence, and incapacitation, and not to achieve forced rehabilitation (i.e., rehabilitation is to be pursued primarily outside of prison); third, to consider other changes in sentencing policy, without departing too much from existing practices; and, fourth, to recognize, while pursuing the goals above, that punishment (especially prison) is expensive and that overcrowding of prisons and other resources must be avoided even if this limits the achievement of certain punishment goals.

\section{B. The Sentencing Commission's Original Intent-the Meaning of "Modified Just Deserts" in Minnesota}

Pursuant to the statutory mandate described above, the Minnesota Sentencing Guidelines Commission developed a set of guidelines in the form of a two-dimensional matrix (Minnesota Sentencing Guidelines Commission 1980, p. 30). The current grid, shown in figure 1, was last revised in 1989 (Minnesota Sentencing Guidelines Commission $1995 b, \S$ IV). There are ten categories of increasing offense severity running down the vertical axis of the grid, and seven defendant criminal history categories (from zero to six or more points) running across the horizontal axis.

The numbers in each cell are presumptive prison durations, in months. Offenders with low to medium criminal history scores, convicted of lower severity offenses, are recommended to receive probation, accompanied by a stayed (suspended) prison term of a specified number of months; for more serious offenses or criminal history scores, the recommended sentence is an executed prison term within a narrow specified range (e.g., forty-four to fifty-two months, at severity level 7 , with zero criminal history).

The boundary between presumptive stayed and presumptive executed prison terms is shown on the grid by a heavy black line known 


\begin{tabular}{|c|c|c|c|c|c|c|c|c|}
\hline \multirow{2}{*}{\multicolumn{2}{|c|}{$\begin{array}{l}\text { Severity Levels of } \\
\text { Conviction Offense }\end{array}$}} & \multicolumn{7}{|c|}{ Criminal History Score } \\
\hline & & 0 & 1 & 2 & 3 & 4 & 5 & 6 or more \\
\hline $\begin{array}{l}\text { Sale of a Simulated } \\
\text { Controlled Substance }\end{array}$ & I & $12 *$ & $12 *$ & $12 *$ & 13 & 15 & 17 & $18-20$ \\
\hline $\begin{array}{l}\text { Theft Related Crimes ( } \$ 2,500 \text { or less) } \\
\text { Check Forgery }(\$ 200-\$ 2.500)\end{array}$ & II & $12 *$ & $12 *$ & 13 & 15 & 17 & 19 & $\begin{array}{c}21 \\
20.22\end{array}$ \\
\hline Theft Crimes (\$2,500 or less) & III & $12 *$ & 13 & 15 & 17 & $\begin{array}{c}19 \\
18-20\end{array}$ & 22 & $\begin{array}{c}25 \\
24-26\end{array}$ \\
\hline $\begin{array}{l}\text { Nonresidential Burglary } \\
\text { Theft Crimes (over } \$ 2,500 \text { ) }\end{array}$ & IV & $12 *$ & 15 & 18 & 21 & $\begin{array}{c}25 \\
24-26\end{array}$ & $\begin{array}{c}32 \\
30-34\end{array}$ & $\begin{array}{c}41 \\
37-45\end{array}$ \\
\hline $\begin{array}{l}\text { Residential Burglary } \\
\text { Simple Robbery }\end{array}$ & $\mathbf{v}$ & 18 & 23 & 27 & $\begin{array}{l}30 \\
29.31\end{array}$ & $\begin{array}{l}38 \\
36-40\end{array}$ & $\begin{array}{r}46 \\
43-49\end{array}$ & $\begin{array}{c}54 \\
50.58\end{array}$ \\
\hline $\begin{array}{l}\text { Criminal Sexual Conduct } \\
\text { 2nd Degree (a) \& (b) }\end{array}$ & VI & 21 & 26 & 30 & $33-35$ & $\stackrel{44}{42-46}$ & $\begin{array}{c}54 \\
50.58\end{array}$ & $\begin{array}{c}65 \\
60.70\end{array}$ \\
\hline Aggravated Robbery & VII & $\begin{array}{c}48 \\
44-52\end{array}$ & $\begin{array}{c}58 \\
54-62\end{array}$ & $\begin{array}{c}68 \\
64.72\end{array}$ & $\begin{array}{c}78 \\
74-82\end{array}$ & $\begin{array}{c}88 \\
84.92\end{array}$ & 98 & $\begin{array}{c}108 \\
104-112\end{array}$ \\
\hline $\begin{array}{l}\text { Criminal Sexual Conduct, 1st Degree } \\
\text { Assault, lst Degree }\end{array}$ & VIII & $\begin{array}{c}86 \\
81-91\end{array}$ & $\begin{array}{c}98 \\
93-103\end{array}$ & $\begin{array}{ll}110 \\
105.115\end{array}$ & 117.127 & $\begin{array}{l}134 \\
129-139\end{array}$ & $14|-15|$ & $\begin{array}{c}158 \\
153-163\end{array}$ \\
\hline $\begin{array}{l}\text { Murder, 3nd Degree } \\
\text { Murder, 2nd Degree (felony murder) }\end{array}$ & IX & 150 & $\begin{array}{c}165 \\
159.171\end{array}$ & 1780 & $\begin{array}{c}195 \\
189-20]\end{array}$ & $\begin{array}{c}210 \\
204.216\end{array}$ & 219.231 & 240 \\
\hline Murder, 2nd Degree (with inrent) & $\mathbf{x}$ & $\begin{array}{c}306 \\
299.313\end{array}$ & 326 & $\begin{array}{c}346 \\
339-353\end{array}$ & $\begin{array}{c}366 \\
359-373\end{array}$ & $\begin{array}{c}386 \\
379-393\end{array}$ & $\begin{array}{c}406 \\
399-4 / 3\end{array}$ & $\begin{array}{c}426 \\
419-433\end{array}$ \\
\hline
\end{tabular}

FIG. 1.-Minnesota Sentencing Guidelines grid, effective August 1, 1989. Source: Minnesota Sentencing Guidelines Commission (1995b). Note: Presumptive sentence lengths are in months. An asterisk $\left(^{*}\right)=$ one year and one day. Italicized numbers within the grid range denote the range within which a judge may sentence without the sentence being deemed a departure. Under state statutes, first-degree murder has a mandatory life sentence.

as the "disposition line." Cases falling in cells above the line generally receive presumptive probation sentences (a few cases above the line have presumptive prison-commit sentences; most of the latter involve repeat sex offenders or use of a dangerous weapon, which are subject to mandatory minimum prison terms under state statutes).

Additional guidelines rules specify when consecutive prison sentences may be imposed; list permissible and impermissible bases for departure from presumptive disposition, duration, and consecutivesentence rules; define a general departure standard ("substantial and compelling circumstances"); and suggest (but do not regulate by presumptive rules) a wide variety of possible conditions of stayed prison sentences. Such conditions may include up to one year of confinement in a local jail, home detention, electronic monitoring, intensive probationary supervision, required appearances at a day-reporting center, inpatient or outpatient treatment, restitution, fines, community service, or (with certain limitations, discussed below) any combination of the 
above conditions (Minnesota Sentencing Guidelines Commission 1995b, \$ III.A.; Minn. Stat. Annot. $\$ 609.135){ }^{12}$

1. The Sentencing Commission's Key Policy Cboices. The commission chose to adopt a "prescriptive" rather than a "descriptive" approach to guidelines drafting (Minnesota Sentencing Guidelines Commission 1980, pp. 2-3; Minnesota Sentencing Guidelines Commission 1984, pp. v, 8-14). Thus the new guidelines were intended to change, not simply model and perpetuate, past judicial and parole decisions. Although prior practices were taken into account, as required by the enabling statute, the commission made a number of independent decisions about which offenders ought to go to prison and for how long. One of the commission's earliest prescriptive choices was its decision to adopt just deserts as the "primary" sentencing goal under the guidelines (Minnesota Sentencing Guidelines Commission 1984 pp. v, 1014), while giving limited scope to other sentencing purposes and considerations - the theory of "modified just deserts" (Minnesota Sentencing Guidelines Commission 1980, p. 9).

The theory needs further elaboration-bow much is desert theory "modified," and by wbat? Clearly, one important nondesert goal was the incapacitation of high-risk offenders. The commission admitted that this goal influenced the precise placement and slope of the disposition line (Minnesota Sentencing Guidelines Commission 1980, p. 9), and it appears that scaling of presumptive prison durations was also influenced by considerations of incapacitation. The commission recognized that recidivists are more likely to reoffend, ${ }^{13}$ and it adopted a grid in which presumptive durations increase substantially, with increases in the defendant's criminal history score. As a result, the impact of criminal history under the guidelines goes well beyond the modest role that von Hirsch would allow prior record to play. ${ }^{14}$

12 The cited statute limits the duration of probationary jail sentences, defines the available "intermediate sanctions," and encourages courts to impose such sanctions "when practicable." The statute further provides that the duration of a stayed felony sentence (and thus the length of probation) may be any period up to the maximum prison term that could have been imposed, or four years, whichever is longer (Minn. Stat. Annot. $\$ 609.135$, subd. 2[a]).

${ }^{13}$ The commission noted that the use of criminal history to increase sentences "has an implicit incapacitative effect, since offenders with longer criminal histories tend to be somewhat greater risks than those with lesser criminal histories. It may also provide an implicit rehabilitative effect, since those with longer criminal histories often have more severe problems and a longer period of control is thought necessary to deal with the problems" (Minnesota Sentencing Guidelines Commission 1984, p. 14).

${ }^{14}$ See von Hirsch $(1981 a$, pp. 619, 632) (defendants deserve full punishment after a "modest" number of convictions; the effect of prior record on prison duration, under the Minnesota guidelines, exceeds what can be justified on desert grounds alone); see 
The commission's implicit pursuit of incapacitative goals may also be reflected in its decision to define "prior" convictions as of the date of sentencing, rather than as of the date that the current offense was committed. Some writers believe that crimes committed after the current offense have no bearing on "desert" (Parent 1988, p. 163); however, such crimes are quite relevant if the goal is to identify and incapacitate (or specifically deter) high-risk offenders. The inclusion, in the criminal history scale, of a point for "custody status" (being on parole, probation, in prison, etc., at the time of the current offense) may also reflect selective incapacitation goals or considerations of specific deterrence.

The commission did not specifically address the goal of general deterrence, except to suggest that it would require a sentencing structure very similar to a desert model (i.e., with more serious offenses assigned the more severe penalties; Minnesota Sentencing Guidelines Commission 1984, p. 12). Presumably, the greater uniformity of guidelines sentences also promotes the goal of general deterrence, by increasing the "certainty" of punishment and decreasing would-be offenders' hopes of leniency (Zimring and Hawkins 1973, pp. 160-72, 207).

Another very important prescriptive choice was the commission's decision to strictly interpret the statutory mandate to consider correctional resources. The commission went further than the statute required and established a goal that state prison populations should never exceed 95 percent of capacity; it then developed a detailed, computerized projection model to test the expected prison population that would result from each proposed version of the guidelines (Minnesota Sentencing Guidelines Commission 1980, pp. 2, 13-14). Resource limitations affected both dispositional and durational decisions, especially the latter (Minnesota Sentencing Guidelines Commission 1980, p. 11).

The commission's other major prescriptive choices included the rank ordering of offense severities; the construction of the criminal history scale; $;^{15}$ and the decision to adopt a disposition line that was "flatter" (i.e., more "desert"-oriented) than would have been sug-

also von Hirsch $(1995$, pp. 154-55, 157) (impact of criminal history on presumptive duration, as well as the steep "slope" of the disposition line, give far too much weight to prior record).

${ }^{15}$ The commission's original criminal history scale included one point for each prior felony; up to one point for multiple prior misdemeanor convictions; up to one point for serious juvenile record; and one point for "custody status." The commission subsequently adopted a "weighting" system for prior felonies (see Sec. IIIC4 below). 
gested by prior sentencing practices, thus sending more low-criminal history "person" offenders to prison (especially those at severity levels 7 and 8), and fewer low-severity, high-criminal-history property offenders (Minnesota Sentencing Guidelines Commission 1980, pp. 215; Minnesota Sentencing Guidelines Commission 1984, pp. 8-14). In addition, the commission adopted a broad goal of sentencing "neutrality" relative to race, gender, and social or economic status (including an explicit rejection of departures based on the offender's employment status at the time of sentencing) (Minnesota Sentencing Guidelines Commission 1995b, $\$ \$$ I(1), II.D.1). Finally, the commission endorsed a principle similar to Morris's concept of "parsimony": to ensure that prison and jail space is available for the most serious cases, sanctions "should be the least restrictive necessary to achieve the purposes of the sentence" (Minnesota Sentencing Guidelines Commission 1995b, $\$ \mathrm{I}[3])$.

Most of the prescriptive policies mentioned above either reflect, or are easily reconciled with, a just-deserts model. As noted in Section II above, mitigation of sentences in order to stay within available resources is consistent with von Hirsch's theory, provided that all sentences are mitigated, without changing the relative severity among different offenses ("ordinal" desert) and provided further that the looser, "cardinal" (absolute) limits of minimum desert are respected.

However, the "parsimony" principle is more problematic. Von Hirsch would only allow such considerations to be used to lower the entire punishment scale; selective, case-level reductions would violate his principle of strict ordinal proportionality. The guidelines' reference to "the purposes of the sentence" suggests consideration of multiple punishment goals and the granting of case-level mitigation unrelated to ordinal desert. The endorsement of case-specific parsimony implies that the commission, like Morris, viewed desert as permitting a range of permissible sanctions; within that range, courts may also consider nonretributive purposes and should impose the lowest penalty which adequately serves all relevant purposes.

The "range" theory above finds further support in the structure and foreseeable application of the guidelines. The Minnesota commission knew that, in the great majority of cases under the new guidelines, judges would retain a wide variety of sentencing options and would continue to apply utilitarian goals and make offender-specific assessments. Under the guidelines, about three-quarters of defendants have presumptive stayed prison sentences (Frase 1993a, p. 299), and the 
commission projected that about 80 percent of defendants would actually receive a stayed sentence. ${ }^{16}$ No minimum "deserved" sentence is specified for presumptive stayed prison cases. However, the guidelines do set upper (maximum) limits on sentence severity in these cases, by means of the presumptive disposition (no immediate prison commitment) and the presumptive duration which applies if an aggravated dispositional departure is ordered, or if the initial stay of prison is later revoked. But the guidelines recommend and assume that departures and revocations will be exceptional. In the absence of departure or revocation, the guidelines do not specify any particular sentence for these defendants. Under Minnesota sentencing laws, such defendants may receive a sentence as light as unsupervised probation or as heavy as a twelve-month jail term (which may also be combined with treatment requirements, strict probation, and other conditions).

Moreover, the guidelines explicitly state that the proper penal objectives to be considered in establishing the conditions of stayed sentences include "retribution, rehabilitation, public protection, restitution, deterrence, and public condemnation of criminal conduct" (Minnesota Sentencing Guidelines Commission 1980, p. 35; Minnesota Sentencing Guidelines Commission 1995b, $₫$ III.A.2). The guidelines further provide that "the relative importance of these objectives may vary with both offense and offender characteristics" and that "multiple objectives may be present in any given sentence."

Thus for at least three-quarters of defendants, the guidelines essentially retain the traditional, offender-based indeterminate sentencing system, with no minimum severity requirements, and with all sentencing purposes allowed. However, maximum prison severity is limited by the presumptive disposition and stayed prison term. The nature and severity of stay conditions was not specifically limited under the original guidelines, but the commission may have expected the principle of parsimony to encourage moderation and attention to the actual need for each additional proposed condition of probation.

Von Hirsch has objected to the "range" theory suggested above. He maintains that the commission was not trying to "systematically" regu-

${ }^{16}$ The projected prison commitment rate for male felons was 20.7 percent and for females, 9.2 percent (Minnesota Sentencing Guidelines Commission 1980, p. 15). Due to a variety of transitional effects, the actual prison rate (for both sexes combined) was only 15 percent in the first year of the guidelines, but the rate has hovered around 20 percent ever since (Frase 1993a, p. 331, table 14; Minnesota Sentencing Guidelines Commission 1995a, p. 17). 
late the sentences in stayed prison cases but was merely "setting forth a maximum applicable to the worst cases," while trying to limit the impact such cases would have on prison populations (von Hirsch 1995, p. 161). It may well be that the commission originally intended its presumptive stay rules as a temporary stopgap and fully intended to later develop more precise, desert-based rules for stay conditions. But the commission's clear endorsement of utilitarian sentencing goals in stay cases strongly suggests that the commission viewed stayed sentences as serving different purposes than prison terms and that it was not planning to develop a strongly desert-centered model for stayed sentences. Nor did the commission subsequently attempt to impose any such model. In the absence of guidance from the commission, the Minnesota Supreme Court began to develop a utilitarian, offender-based theory of stayed sentences and dispositional departures; the court also interpreted the commission's stayed prison durations as limiting not just the prison terms for cases of dispositional departure or stay revocation but also the maximum ordinarily deserved severity of probation sanctions in each guidelines cell above the disposition line.

As for the minority of defendants with presumptive executed prison terms, the commission adopted very narrow presumptive sentence ranges, which suggests a much stronger emphasis on (modified) just deserts. But here, too, the commission's rules do not strictly control minimum sanction severity, and the commission must have expected that utilitarian sentencing purposes would continue to play an important role in mitigating sentences. The guidelines imposed no limits at all on charging and plea-bargaining concessions, which can easily be used to mitigate presumptive prison terms. The commission must have expected that prosecutors and judges would continue to consider offender-based, utilitarian sentencing goals in deciding to grant or deny such concession (and it appears that they have done so; see Sec. IIIC3 below). Nor did the commission explicitly forbid courts from basing departures on nonretributive grounds. Although the commission's lists of allowable departure factors are mostly desert-related, these lists are expressly not exclusive (Minnesota Sentencing Guidelines Commission $1995 b, \S$ II.D.2). Given the pervasive practice of plea bargaining related to offender as well as offense factors, and the open-ended lists of permissible factors, it could be expected that many departures-especially mitigations-would continue to be based on nonretributive grounds.

Perhaps the commission intended to take up these issues later and 
close the theoretical "loopholes" described above. But it never announced such an intention, nor did it ever even begin to consider these issues; in the absence of commission action or guidance, courts and attorneys quite reasonably assumed that the commission tacitly accepted the legitimacy of a more flexible, multipurpose model of sentencing.

\section{The Evolution of Sentencing Theory since 1980}

The rough outlines of a limiting retributive theory, suggested by the enabling statute and the original version of the guidelines, have become much clearer since 1980. Important contributions to this evolution were made by appellate case law, legislative enactments, the actual practices of judges and attorneys, and some of the commission's own proposed amendments.

1. Major Theory-Related Guidelines Case Law. The appeal rights granted to defendants and prosecutors under the guidelines have generated a rich body of appellate case law, fully realizing Morris's ideal of an evolving "common law of sentencing."

The Minnesota Supreme Court almost immediately established the principle that sentence enhancement must generally be based on aggravated circumstances of the conviction offense and may not be based on the details of offenses dismissed or never filed (Minnesota Sentencing Guidelines Commission 1984, pp. 111-13). ${ }^{17}$ The court also established that durational departures may not be based on assessments of the individual defendant's dangerousness (State v. Hagen, 317 N.W.2d 701, 703 [Minn. 1982]) nor on special needs for deterrence (State $v$. Scbmit, 329 N.W.2d 56, 58, n. 1 [Minn. 1983]) or for extended, inprison treatment (State v. Barnes, 313 N.W.2d 1 [Minn. 1981]). In State v. Evans (311 N.W.2d 481 [Minn. 1981]), the court ruled that upward durational departures should normally not exceed twice the presumptive duration (although in "rare," exceptionally aggravated cases, the trial court may depart all the way up to the statutory maximum). Uniformity goals were further strengthened by the court's early announcement that trial court decisions not to depart will rarely warrant reversal on appeal (State v. Kindem, 313 N.W.2d 6 [Minn. 1981]).

\footnotetext{
${ }^{17}$ However, some presumptive sentences are determined by factors (e.g., dollar amount of loss) which need not be proven as an element of the conviction offense; moreover, most upward departures are based on nonelemental facts (e.g., unusual cruelty to the victim), and a few involve facts which are not even part of the same course of conduct (e.g., "major economic offense" by defendant involved in other similar conduct) (Frase $1993 a$, p. 288, n. 29; Minnesota Sentencing Guidelines Commission 1995b, \$ II.D.2.b).
} 
In State v. Randolph (316 N.W.2d 508 [Minn. 1982]), the court held that the trial judge must grant a defendant's request for execution of the presumptive stayed prison term whenever the judge's proposed conditions of a stayed sentence are so onerous that they would, in the aggregate, be more severe than that prison term. This case, in effect, limits maximum sanction severity in stayed prison cases and thus reinforces and extends the commission's implicit policy of setting upper (but not lower) limits on sanction severity in these cases.

In State v. Hernandez (311 N.W.2d 478 [Minn. 1981]), the court held that criminal history points may accrue on a single day when defendants are sentenced concurrently for multiple offenses. Thus a defendant with no previous convictions who was sentenced concurrently on four separate felonies (one point each) would have a criminal history of three when he was sentenced on the fourth count. Prior to Hernandez, prosecutors could serialize prosecutions to achieve the same result, and all additional concurrent counts would increase the defendant's future criminal history if he committed further offenses, but Hernandez increases the immediate impact (and plea-bargaining leverage) of multiple counts. The Hernandez rule also helps prosecutors target "high-rate" offenders and thus further emphasizes the utilitarian (incapacitative) purposes which were already implicit in the commission's criminal history scale (in particular: the inclusion of convictions as of the date of sentencing, rather than as of the date of the current offense, and the substantial weight given to criminal history in determining the presumptive disposition and duration).

In another very significant line of cases, the court held that dispositional departures (but not durational departures) may be based on individualized assessments of the offender's "amenability" to probation or prison. ${ }^{18}$ In State v. Park (305 N.W.2d 775 [Minn. 1981]), the Minnesota Supreme Court upheld an upward dispositional departure (i.e., commitment to prison, rather than the presumptive stayed term) because of the defendant's unamenability to probation. The latter finding was based on the defendant's serious chemical dependency problem, his refusal to accept that he had a problem or needed treatment, and his complete failure to cooperate during previous probation terms.

In later cases, the supreme court applied several other "amenability" concepts to uphold downward dispositional departures (i.e., granting

\footnotetext{
${ }^{18}$ These cases are discussed at length in Frase (1991a, pp. 740-48). A similar line of cases, under the federal sentencing guidelines, is discussed in Frase (1991b).
} 
probation-usually accompanied by a short jail term and/or required residential treatment-in lieu of the presumptive executed prison term). In State v. Wright (310 N.W.2d 461 [Minn. 1981]), the departure was based on two independent grounds. First, the court found that the defendant was unusually vulnerable, and was therefore unamenable to prison, because his extreme immaturity would cause him to be victimized or led into criminal activity by other inmates. Second, the court found that the defendant was particularly amenable to treatment in a probationary setting; he needed psychiatric care unavailable in prison and would not endanger public safety provided he received appropriate outpatient treatment.

In State v. Trog (323 N.W.2d 28 [Minn. 1982]), the court upheld a downward dispositional departure based solely on the defendant's particular amenability to probation. The presentence report indicated that, prior to the current offense (burglary with assault) Trog had been an "outstanding citizen," with no police record of any kind, even as a juvenile; he had also done well in school and at work, was intoxicated at the time of the offense, had cooperated fully with the police, and was shaken and extremely contrite about the incident. The departure in this case appears to be based on the aberrational and uncharacteristic nature of the defendant's crime, rather than on any particular treatment needs. The supreme court also quoted with approval the testimony of a retired chief of the police juvenile division, that nothing would be served by sending Trog to prison. This case provides a clear example of the rejection of strict, desert-based lower limits on punishment; Trog's sentence was mitigated for reasons of utilitarian "parsimony"-greater severity would serve no social purpose and might even be harmful.

Of all the theory-related decisions described above, the "amenability" case law seems most out of character with the dominant "justdeserts" theory of the guidelines. The supreme court has never explained why it limited this doctrine to "dispositional" departures (stay or execution of prison) or how amenability departures relate to the structure and purposes of the guidelines. However, as I have argued at greater length elsewhere (Frase 1991a, pp. 740-48), a closer analysis of the amenability cases reveals that they are quite consistent with the guidelines and are supported by strong practical and policy considerations. The following is a summary of the main points of that argument.

First, as noted in Section III $B$ above, the guidelines strongly imply 
that stayed sentences serve different and broader purposes than prison terms. The guidelines also state that dispositional and durational departures are separate decisions, requiring separate justification (Minnesota Sentencing Guidelines Commission 1995b, comment II.D.02), and the guidelines do not limit either type of departure to retributive grounds. ${ }^{19}$ The supreme court's amenability cases reconcile these policies by treating dispositional presumptions and departures as primarily offender-based, ${ }^{20}$ whereas durational presumptions and departures are entirely offense- and culpability-based (State v. Heywood, 338 N.W.2d 243, 244 [Minn. 1983]).

Second, the offender-based disposition theory above finds support in the manner in which the guidelines regulate stayed sentences. Judges are given broad discretion not only to base stay conditions and severity on nonretributive grounds but also to revoke stayed sentences based on technical violations and other indicia of "unamenability" to probation. Such revocations are difficult to reconcile with a theory that assumes that probation was all the defendant deserved, and will ever deserve, for the original offense (Parent 1988, p. 231; von Hirsch, Wasik, and Greene 1989, p. 609). The simplest answer to this retributive anomaly is that such a defendant did deserve the presumptive prison term provided for his original offense and prior record (for further discussion of this, see Sec. IV $A$ below) but was initially given less in an attempt to achieve the utilitarian purposes of probation (rehabilitation, restitution or community service, and "parsimony"). Any subsequent revocation is justified not only by the need to deter probation violations but also by acts of the defendant that suggest that he is unamenable to probation and should now be given his full (modified) deserts. But why did we think that such a defendant was "amenable" in the first place? The answer must be: because he was presumed to be amenable, given his less serious offense and prior record. From this theory, it was a short step to conclude that, in exceptional cases, judges may decide at the outset that the presumption of amenability has been overcome, thus justifying an aggravated dispositional departure. Such departures, like stay revocations, reflect a theory of "limiting" retribu-

\footnotetext{
${ }^{19}$ The commission has expressed concern that amenability departures may permit race and class bias but has declined to forbid them (see Sec. IVC4 below).

${ }^{20}$ Although dispositional departures are generally offender-based, courts may, and occasionally do, depart dispositionally for reasons related solely to culpability. See, e.g., State v. Olson, 325 N.W.2d 13 (Minn. 1982) (mitigated departure) and State v. Gartland, 330 N.W.2d 881 (Minn. 1983) (aggravated departure).
} 
tivism: retributive values determine the maximum deserved punishment (prison duration), while utilitarian goals (along with considerations of parsimony and uniformity) determine initial and subsequent disposition decisions.

Third, a similar theory explains mitigating amenability departures in presumptive commit cases: such offenders are normally presumed to be unamenable to probation, but this presumption, too, may be overcome in exceptional cases.

Fourth, since there are no guidelines or other legal controls over stay revocations, charging, and plea bargaining, judges and prosecutors could and probably did achieve similar results without the use of aggravating and mitigating "amenability" departures. Formal recognition of such departures merely encourages courts and prosecutors to make these decisions openly, stating reasons. Open decision making is consistent with the "truth-in-sentencing" theme of the guidelines (Frase $1993 a$, p. 281) and permits adversary argument, appellate review, and commission guidance, rather than subterfuge and evasion. The latter dangers would be particularly great in such a heavily treatmentoriented state (Frase 1993a, p. 334); Minnesota, "the land of 10,000 lakes," is also sometimes called "the land of 10,000 treatment centers."

Fifth, given the ease with which the same results can be achieved informally, formal recognition of amenability departures does not significantly add to sentencing disparity or undercut the deterrent value of presumptive prison terms. In practice, amenability departures are limited to exceptional cases and do not appear to be granted in a racially discriminatory manner. ${ }^{21}$ It can also be argued that individualized amenability assessments are sufficiently reliable, provided they are limited to fairly clear-cut (i.e., exceptional) cases. Indeed, even von Hirsch seems to accept occasional dispositional departures for "amenable" or "responsive" individuals (von Hirsch, Wasik, and Greene 1989, pp. 606, 614).

Sixth, amenability departures help to conserve scarce correctional resources. Probation services are not wasted on clearly unamenable offenders (nor are the latter likely to be made much worse if sent to prison). Amenable offenders can be effectively treated in the community, often at lower cost, while avoiding harmful prison influences,

${ }^{21}$ See Frase 1993a, pp. 326-28 (mitigated amenability departures occur in about 15 percent of presumptive prison-commit cases; aggravated amenability departures occur in less than 1 percent of cases with presumptive stayed prison terms). 
conserving prison beds for dangerous offenders and promoting parsimony.

Seventh, all three of the leading amenability decisions summarized previously (Park, Wright, and Trog) were joined by the two former members of the guidelines commission, Justices George Scott and Douglas Amdahl, and the Trog opinion was written by Amdahl (who also wrote many other leading guidelines opinions, including Randolph and Hernandez). Thus at least two of the original nine drafters of the guidelines saw no fundamental conflict between amenability concepts and the commission's "original intent."

2. Legislative Developments Related to Sentencing Theory. As noted earlier, the legislature which enacted the 1978 guidelines enabling statute wanted sentencing to become more uniform, with prison duration no longer based on individualized treatment or parole-risk assessments; at the same time, the legislature also remained committed to the pursuit of crime-control goals and sound fiscal and prison management.

Subsequent legislation has reinforced the importance of crime-control goals. Numerous laws have been enacted permitting judges to make individualized assessments of offender dangerousness ${ }^{22}$ or amenability to treatment, for certain, narrowly defined groups of offenders (Frase 1993b, pp. 356-57, 360-63). The legislature has also enacted additional crime-control-motivated mandatory minimum statutes (Frase 1993b, pp. 356, 360, 363). In 1989, the legislature amended the guidelines enabling statute to specify that the commission's "primary" consideration in drafting guidelines should be "public safety." In 1993, the enabling statute was further amended to provide that violations of prison "disciplinary" rules (which form the basis for loss of goodtime credits) may include "refusal to work" and "refusal to participate in treatment or other rehabilitative programs" (Minn. Stat. Annot. $\$ 244.05$, subd. $1 \mathrm{~b}[\mathrm{~b}])$.

3. Sentencing Theories Implicit in Guidelines Practices. Empirical analysis of charging and sentencing practices under the guidelines suggests that attorneys and trial courts remain firmly attached to offenderbased, crime-control-oriented sentencing goals (Frase 1993a, pp. 295-

\footnotetext{
${ }^{22}$ In 1994, the legislature enacted a civil commitment statute for "sexually dangerous persons" (Minn. Stat. Annot. $\$$ 253B.02, subd. 18b and 253B.185). This new law, as well as an older statute covering "psychopathic personalities" (Minn. Stat. Annot. $\$ 9$ 253B.02, subd. 18a and 253B.185), are being applied with increasing frequency to chronic sexual offenders who are nearing the end of their prison sentences.
} 
328). Prosecutors have used their charging discretion to avoid presumptive and mandatory-minimum prison terms, especially for highseverity-level "person" offenders with very low criminal history scores and for low-severity-level weapons offenders (who are subject to presumptive prison sentences even if their cases fall above the disposition line). Prosecutors have also used their charging and plea negotiation powers to steadily increase the average criminal history scores of property offenders. By filing or retaining additional counts, prosecutors can push low-severity recidivists across the grid, thus increasing their presumptive prison duration and making more of them eligible for presumptive prison-commit sentences.

As for judicial decisions, departure rates have gradually increased, with mitigating departures far outweighing aggravated departures in all years (Frase 1993a, pp. 296-328; Minnesota Sentencing Guidelines Commission 1995a, pp. 35, 37, 42). Aggravated, "unamenable-to-probation" departures remain extremely rare, but mitigated, "amenableto-probation" departures are granted in about 15 percent of presumptive prison cases (and account for about half of all mitigated dispositional departures). Multiple regression analysis of mitigated and aggravated dispositional departures and of the imposition of jail as a condition of probation reveals that criminal history factors-especially "custody status" (probation, parole, etc., at the time of the current offense)-are consistently among the strongest predictive factors, usually much stronger than offense severity or offense type. Method of disposition (guilty plea vs. trial) is also usually a strong predictor of sentence severity, among otherwise comparable cases, but race is generally not a significant independent explanatory factor. Analysis of the limited data available on demographic variables indicates that offender employment continues, as it was before the guidelines, to be a significant predictor of a noncustodial sentence (Minnesota Sentencing Guidelines Commission 1991, pp. 15-18; Dailey 1993, p. 774)-even though the guidelines have always listed this as an impermissible departure factor (Minnesota Sentencing Guidelines Commission 1995b, \$ II.D.1).

The high rates of sentence mitigation, via charge reduction or formal departure, suggest once again that the guidelines have been much less successful in setting lower limits on sanction severity than in setting upper limits. The strong influence of prior record (even beyond its formal role in determining the presumptive disposition and duration), together with the important role of the offender's employment status and "amenability" to probation, result in a system in which both the 
form and the severity of sanctions are often determined by utilitarian, offender-based assessments, rather than by considerations of desert. These findings are consistent with Morris's limiting retributivism theory, in which desert (as measured by conviction offense and prior record) sets strict upper limits on sanction severity, but where many offenders receive lesser penalties whose precise severity is determined primarily by nonretributive considerations (crime control, resource limits, and "parsimony").

4. Important Commission-Initiated Amendments. The commission has made many changes in the guidelines since 1980. Most are consistent with its original, modified deserts approach (e.g., the decision in 1989 to weight prior felony convictions according to their guidelines severity level ranking; Minnesota Sentencing Guidelines Commission 1995b, $\$$ II.B.1). However, the commission's occasional modifications of the presumptive prison durations in certain grid cells are harder to justify, since they violate the important concept of "ordinal" proportionality (relative severity of sanctions, among different offenses and offenders; see Sec. IL $A$ above). Reductions in certain durations at low severity with medium-to-high criminal history were motivated by a need to avoid expected prison overcrowding (Minnesota Sentencing Guidelines Commission 1984, p. 92), rather than by any decision that the prior durations exceeded ordinal desert. On several occasions (especially in 1989), presumptive durations for violent offenses were substantially increased. Although some commissioners may have felt that these durations had always been too low, the principle motivating factor behind these changes was political pressure to respond to increased rates of drug and violent crime (Frase 1993b, pp. 359-61).

The commission has never seriously addressed any of the guidelines ambiguities or omissions that have allowed courts and attorneys to continue to strongly pursue nondesert goals. Thus no attempt has been made to regulate charging and plea-bargaining mitigations, stay revocations, or stay conditions, nor has the commission made any major attempt to clarify what theories of punishment may be considered as grounds for departure.

The commission has on several occasions considered the possibility of enacting stay guidelines (most recently in 1988-89, pursuant to a legislative directive to consider the issue). Each time, the commission backed away from recommending any specific guidelines. This was partly for practical reasons, in particular, local resource limits and massive field resistance. But it was also because there was a lack of commis- 
sion consensus on the primary sentencing goals to be served in stay cases (Minnesota Sentencing Guidelines Commission 1989, pp. 20, $35)$.

In 1989, the commission added two sentences to the guidelines commentary (Minnesota Sentencing Guidelines Commission 1995b, Comment II.D.101), requiring the trial court to demonstrate that an amenability departure is not based on impermissible social or economic factors. But the commission expressly declined to forbid all amenability departures and did not otherwise change or clarify the guidelines departure standards or lists of permissible and impermissible departure standards.

\section{Summary}

The Minnesota guidelines were, from the outset, a very "modified" version of just deserts and have become even more so over time. Although the original guidelines emphasized just deserts, they also retained a major role for nonretributive sentencing goals. First, the strong influence of criminal history, in determining presumptive dispositions and durations, tests the limits of even the broadest conceptions of "desert" and clearly exceeds the role which von Hirsch finds acceptable. Second, although presumptive disposition and duration rules set fairly strict "modified desert" limits on maximum sanction severity, they impose no limits on minimum severity in presumptive stay cases and (because charging discretion is not controlled) set rather weak lower limits in presumptive commit cases. Third, utilitarian sentencing purposes are explicitly endorsed in the determination of stay conditions and are not precluded as factors in charging, plea bargaining, or decisions to revoke a stayed sentence; utilitarian purposes are also implicit in the guidelines' endorsement of case-specific "parsimony."

Postimplementation legislation and appellate case law have each reinforced the importance of nonretributive goals. Case law has increased the importance of criminal history and has given formal recognition to dispositional departures based on the offender-based, nonretributive concept of "amenability" to prison or probation. Statutes have also endorsed the concept of amenability, while encouraging courts and the commission to promote public safety (especially by increasing sentence severity for dangerous offenders).

Analysis of sentencing practices under the guidelines confirms the strong continuing influence of utilitarian sentencing goals, especially 
rehabilitation, incapacitation, and the need to make efficient use of limited correctional resources. Minnesota has been especially successful in avoiding prison overcrowding and promoting the parsimonious use of prison sentences (Frase 1993a, pp. 329-33). Minnesota's percapita prison population remains lower than any other state with a major metropolitan area - only North Dakota has a lower rate (Bureau of Justice Statistics 1995, p. 3, table 2). Moreover, the increases in Minnesota's prison population since 1980 have primarily been due to increased felony caseloads (Frase 1995a, p. 194, fig. 7.6). During the same time period, of course, other states and the federal system experienced dramatic increases in sentencing severity and inmate populations, and these increases do not appear to be explained by rising crime rates (Frase 1995a, p. 194, fig. 7.7 and accompanying text). ${ }^{23}$

Nor has Minnesota's parsimonious use of prison sentences resulted in escalating crime rates. The major increases in rates of reported crimes, arrests, and felony caseloads in Minnesota, since the guidelines became effective, have involved violent and drug offenses; index property crime rates have actually fallen by about 11 percent (Federal Bureau of Investigation 1981, p. 52; Federal Bureau of Investigation 1994, p. 72; Minnesota Sentencing Guidelines Commission 1995a, p. 49). But, compared with other states, Minnesota sentences are relatively severe for drug and violent crimes (Minnesota Sentencing Guidelines Commission 1992, p. 1; Frase 1993c, pp. 28-32); "parsimony" has been achieved through community-based sentencing of property offenders.

Minnesota's experience thus lends support to Morris's view that the severity of criminal penalties has very little effect on overall crime rates (Morris 1977b, pp. 267-69; Morris 1993, p. 309). In line with Morris's strong endorsement of the principle of parsimony, Minnesota's experience further suggests that other states could substantially reduce their overall rates of incarceration, with no loss in crime-control effectiveness, and at great savings in public expense and private hardship.

\section{Limiting Retributivism and Minnesota Sentencing Policies}

There are numerous similarities between the theory of punishment that has evolved under the Minnesota guidelines and Morris's theory

\footnotetext{
${ }^{23}$ In the absence of comparable data on criminal caseloads, the best available base for cross-jurisdictional comparisons of prison populations is adult arrests, weighted according to the seriousness of the offense. In the cited study, arrests for violent crimes were weighted (multiplied) by a factor of ten. Total inmate populations (prison plus jail)
} 
of limiting retributivism. The similarities are particularly strong when sentencing practices in Minnesota are examined.

"But"-as Morris likes to say-there are a number of differences. And yet on closer inspection, many of these differences are either minor shifts in emphasis or degree or else reflect practical considerations of the kind that Morris has often noted and to which he would certainly be sympathetic.

In the following discussion of major similarities and differences, I often refer for convenience simply to "Morris" and "Minnesota." But as shown in Section III above, Minnesotans do not always speak with a single voice on these matters; thus I occasionally note the differing views or emphasis that appear in the guidelines commission's theoretical pronouncements and aspirations, in the guidelines themselves, in occasionally discordant state statutes, in guidelines case law, and in actual practices.

\section{A. Desert Limits}

Both Morris and Minnesota recognize fairly strict, desert-based limits on maximum sanction severity, with relatively weak limits on minimum severity (or none at all). Both base their assessments of desert on the offender's current conviction offense and prior record, and both give substantial weight to prior record.

1. Upper Limits on Sanction Severity. For Morris, the upper limits of desert may not be exceeded for any reason. Minnesota comes close to, but does not quite achieve, this humane and principled constraint.

Durational Rules. The guidelines presumptive prison durations define the ordinary maximum of desert. Guidelines departure rules, together with appellate case law, further provide that these upper durational limits may only be exceeded for reasons of case-specific desert, on a showing of "substantial and compelling circumstances" demonstrating aggravated culpability or harm. Only in rare, exceptionally aggravated cases may an upward durational departure exceed twice the presumptive duration (in which case, the statutory maximum becomes the upper limit).

"But"-various "dangerous offender" statutes enacted in 1989 and 1992 permit or even require aggravated durational departure, imposi-

at year end were analyzed as a percent of weighted adult arrests for that calendar year. The arrest-based incarceration rates for Minnesota and for the United States as a whole were very similar, from 1975 through 1980 . But from 1981 through 1991, Minnesota incarceration rates remained constant, while the U.S. rate increased by 80 percent. 
tion of the maximum statutory term, or use of extended maximum terms for certain offenders (Frase 1993b, pp. 356-57, 360-63). Such statutes appear to permit sentences in excess of maximum desert (as measured by guidelines on presumptive durations and departure rules). However, these statutes are narrowly drafted and thus infrequently used. Furthermore, it appears likely that adoption of such statutes in 1989 was the political "price" for not enacting a death penalty or broader increases in sentencing severity (Frase 1993b, pp. 359-60). In light of the extreme political pressure to respond to increased rates of violent and drug crime, adherence to von Hirsch's more rigid model of "ordinal" desert might very well have resulted in elevation of the entire sentencing scale, thus increasing overall severity (and probably also increasing formal and informal [charge-induced] departure rates, thereby decreasing uniformity and race and class neutrality). Nevertheless, such selective, seemingly undeserved sentence enhancements are very troubling to Morris, who questions whether it is proper to "deal unjustly with a few so that we can persuade the legislature to deal more effectively and fairly with the many" (Morris 1974, p. 65).

Moreover, adoption of these special, sentence-enhancement statutes did not prevent the legislature and the commission, in 1989, from also substantially raising presumptive durations for offenders at severity levels 7-10. For example, the presumptive durations for defendants at these four levels, with zero criminal history, were raised from 24,43 , 105 , and 216 months, ${ }^{24}$ respectively, to $48,86,150$, and 306 months. (Curiously, the greatest proportionate increases were for offenders with the lowest criminal history scores.) These increases were primarily motivated by rising crime rates and public fear, rather than any reevaluation of ordinal desert.

If they were not so large, the durational increases described above might be consistent with Morris's theory, since he viewed crime rates and the public's fear of crime as relevant factors in the determination of maximum desert. Even if Morris would reject such substantial increases on desert grounds, he might-despite his concerns about injustice to the "few"- concede that political realities sometimes create hard choices for policy makers, with no clear "right" answer. And he would certainly appreciate Minnesota's continued success, even after 1989 , in limiting the use of prison sentences. The overall pattern of

\footnotetext{
${ }^{24}$ Presumptive sentences at levels 9 and 10 had already been raised once; prior to 1983, the durations at these severity levels (for defendants with zero criminal history) were 97 and 116 months, respectively.
} 
Minnesota sentencing remains closer to Morris's model of custodial "parsimony" and community-based corrections than any other American jurisdiction.

The sentencing guidelines commission has also lowered some of its presumptive durations, to avoid prison overcrowding. Thus in 1983, the commission lowered the durations at severity levels 1-3, for offenders with criminal history scores of 2 or greater. Such reductions are quite easy to justify under Morris's flexible theory of desert (especially regarding lower or minimum desert requirements) but are inconsistent with von Hirsch's strict requirements for ordinal spacing of penalties. Under von Hirsch's theory, Minnesota's choices would have been to lower all penalties, build more prisons (if that could be done in time), or do as most states have done: operate overcrowded prisons.

Dispositional Rules. Under the guidelines, presumptive stayed prison terms may be revoked if the defendant violates probation and, very exceptionally, may be executed ab initio if the offender is found unamenable to probation. Such probation revocations and "upward" dispositional departures do not require a case-specific finding of increased desert. However, these practices are still consistent with a recognition of strict upper desert limits-provided that one views a prison term, equal in length to the presumptive stayed term, as the offender's maximum desert (Frase 1991a, pp. 742-47).

Support for the latter view is found in the commission's own work, as well as in guidelines case law. The commission views its guidelines as strongly desert-based, yet it has never required stay revocations and upward dispositional departures to be based on findings of increased desert. This implies that the presumptive durations of prison specified for stay cases are already presumed to be "deserved" but that most offenders are recommended to initially receive less than their full deserts. The apparent reasons for this leniency are to achieve parsimony and to permit judges to consider a variety of nondesert purposes (the guidelines explicitly authorize courts to consider such purposes, in determining the conditions of stayed sentences). The Minnesota Supreme Court implicitly accepted this "already deserved" theory when it held that dispositional departures may be based on defendant "unamenability to probation," with no showing of increased culpability (State v. Park, 305 N.W.2d 775 [Minn. 1981]). In contrast, all upward durational departures require a showing of increased culpability and may not be based on "unamenability" (State v. Jackson, 329 N.W.2d 66 [Minn. 1983]). 
Furthermore, the structure of presumptive sentence durations on the guidelines grid strongly suggests a direct link between stay durations and desert. As shown in the current grid in figure 1, these durations increase smoothly and proportionately across each row within each severity level, with no noticeable "break" at the disposition line. Durations also increase fairly steadily within each column of the grid, and this was even more true in the commission's original, 1980 grid. $^{25}$ The largest cell-to-cell jumps in presumptive duration correspond to severity level and criminal history increases, rather than to the location of the disposition line. The supreme court evidently agreed that stay durations measure maximum desert, when it decided that defendants may demand execution of the presumptive stayed term if proposed stay conditions are, in the aggregate, more onerous than such a term would be (State v. Randolph, 316 N.W.2d 508 [Minn. 1982]).

As noted in Section III above, von Hirsch has objected to the above theory, arguing that the commission was not trying to "systematically" regulate sentences in stayed prison cases but was merely setting forth a maximum applicable to the worst (i.e., most culpable) cases. But von Hirsch's "worst offenders" theory does not fit the pattern of presumptive durations on the Minnesota guidelines grid. His theory implies that these durational numbers mean very different things on either side of the disposition line-_aggravated culpability" durations above the line and "ordinary culpability" durations below. Yet, the durational numbers generally increase smoothly across and down the grid and show no systematic shifts across the disposition line. If anything, the increases in presumptive durations accelerate, rather than pause or slow down, as one crosses the disposition line from the supposed zone of "aggravated" culpability durations to the zone of "ordinary" culpability durations.

Von Hirsch has also objected that the "already deserved" theory above would permit courts routinely to sentence minor offenders to prison (von Hirsch 1994, p. 45). However, this should not occur frequently under Minnesota's theory, nor has it occurred in practice; Minnesota's emphasis on uniformity, combined with the goal of parsimony, yields a very strong presumption in favor of the recommended stayed sentence and discourages probation revocation. In practice, upward dispositional departures are very rare (Frase 1993a, p. 326), and

${ }^{25}$ In 1980 , the presumptive durations in the first three columns at severity level 6 were (and remain today) twenty-one, twenty-six, and thirty months. At level 7 the durations were twenty-four, thirty-two, and forty-one months. 
probation revocation rates have also been modest in most years (Frase 1993d, p. 10).

2. Lower Limits on Sanction Severity. In Minnesota, as under Morris's theory, lower desert limits are often not present and, when present, are much more flexible than the upper limits described above. In presumptive stay cases (over 75 percent of the caseload), the guidelines impose no requirements of minimum sanction severity. ${ }^{26}$

As for presumptive prison-commit cases, the guidelines do prescribe minimum severity limits (i.e., the low end of the range of presumptive prison terms in each grid cell). However, these formal limits are often avoided by means of departures and charging mitigations. The mitigated dispositional departure rate for these cases has varied between 19 and 34 percent (Minnesota Sentencing Guidelines Commission $1995 a$, p. 37). If de facto departures achieved by charging leniency are included, the mitigated dispositional departure rate is over 40 percent (Frase 1993a, p. 302, table 1).

Finally, consistent with Morris's views, Minnesota statutes impose relatively few mandatory-minimum prison terms or probation exclusions. Moreover, the two most frequently applicable "mandatory" minimum statutes actually contain provisions allowing for the grant of probation under certain circumstances (Minn. Stat. Annot. $\$ 609.11$, subd. 8 [certain offenses committed with a firearm or other dangerous weapon]; Minn. Stat. Annot. $\$ 609.342$, subd. 2 [sex-offense recidivists]). In practice, probation is very frequently granted in these two groups of cases, especially for defendants whose cases fall above the disposition line (Frase 1993a, p. 309).

3. Width of Ranges, between Maximum and Minimum Desert. Morris would probably view the allowable ranges in Minnesota's guidelines cells as either too narrow or too broad. For presumptive commit defendants, the range of presumptive prison terms is very narrow, especially in the upper right corner of the grid (e.g., eighteen to twenty months). It would be quite difficult to apply much "fine-tuning" within such a narrow range. However, in practice, this may not be a serious problem given the frequently used power to mitigate sentence durations via departures and charge reductions.

In the case of presumptive stay defendants, the "desert range" (from zero to twelve to zero to thirty months, depending on the cell) may be

\footnotetext{
${ }^{26}$ There are, however, a few statutory provisions imposing minimum jail terms; see, e.g., Minn. Stat. Annot. $\$ 609.583$ (presumptive sentence for first-offense residential burglary is a ninety-day jail term, restitution, or community service).
} 
broader than Morris would prefer. For example, he suggests that a range of probation (zero custody) to six months would be appropriate for second-offense purse-snatchers (Morris 1982, pp. 194-95). However, to say that a range is appropriate does not necessarily mean that a broader range would be inappropriate, and Morris has always given greater emphasis to upper (maximum) severity limits than to lower limits or the goal of equality per se. Thus his principal objection here would probably not be that the range is too broad but rather that there are no guidelines at all for the selection of intermediate punishments within that range.

4. Case-Specific Desert. Morris and Minnesota agree that casespecific desert considerations are part of the "fine-tuning" of the sentence, within the normally applicable limits of maximum and minimum desert. Morris primarily addressed mitigation based on mental illness (Morris 1982, pp. 168-69), but in doing so he appeared willing to accept other desert-based, case-specific reasons for adjusting the severity of the penalty.

5. The Meaning of "Modified" Desert in Minnesota. The Minnesota commission stated that its original guidelines were based on a theory of "modified just deserts" (Minnesota Sentencing Guidelines Commission 1980, p. 9). Von Hirsch also discusses this concept, but his usage differs from the meaning of "modified" deserts in Minnesota-especially as the guidelines have evolved over time. Morris does not mention this term, but his more flexible conception of desert permits a wide variety of sentencing practices to be viewed as falling within the range of "deserved" punishment for the offense of conviction. Minnesota's version of "modified" desert appears to be much closer to Morris's "range" theory than to von Hirsch's conception.

In von Hirsch's view, "modified" desert means a "desert-based hybrid" which permits restricted departures from desert, in order to achieve nondesert sentencing purposes. Such departures are said to be of two types: "substantial" departures, limited to "extraordinary situations; or more "routine" departures, "with fairly narrow limits on their permissible extent" (von Hirsch 1994, p. 48, n. 3; see also von Hirsch 1993, chap. 6). Minnesota's recent "dangerous offender" legislation, appears to fall within von Hirsch's first category.

However, Minnesota also permits at least two types of "routine" departure from von Hirsch's conception of strict, ordinal desert. These would have to fit within von Hirsch's second category, but neither appears to respect his requirement of "fairly narrow limits" on the extent 
to departure. The very broad range of sanction severity in presumptive stay cases, accompanied by explicit acceptance of nondesert goals, would seem to permit routine and major departures from strict ordinal desert. Alternatively (and more plausibly, given the Minnesota commission's strong emphasis on desert), the treatment of presumptive stay cases suggests a more flexible, Morris-style "range" conception of the meaning of "desert" itself.

Similarly, the strong effect of prior record on presumptive dispositions and durations in Minnesota not only exceeds the role that von Hirsch would allow this factor to play in a purely desert-based system (von Hirsch 1985, pp. 77-91; von Hirsch 1994, pp. 39-40), it may also exceed the "narrow limits" of his second category of "modified" desert, described above. ${ }^{27}$ Again: did the Minnesota commission really intend to authorize routine and major "departures" from desert? Or did it simply have a more flexible conception of "desert" than von Hirsch would accept?

The Minnesota Supreme Court apparently does not view the strong role of prior record as a "departure" from desert. The steep upward "slope" of the disposition line, for offenders with three or more criminal history points, involves no "departure" from desert because the court views all disposition decisions as primarily raising issues, not of what is deserved, but rather of the form of punishment (and whether the defendant should receive his full deserts); under the court's amenability case law, duration decisions are the measure of what is deserved.

The supreme court does not seem to view the long presumptive durations assigned to offenders with high criminal history scores as exceeding "deserved" punishment. The court has repeatedly stated that durational departures must be justified by atypical, case-specific culpability. But if the presumptive durations for high-criminal-history offenders were viewed by the court as exceeding desert-presumably for utilitarian reasons-then the court should have been willing to permit such nondesert reasons to be used to depart up or down from the presumptive duration. This would be especially appropriate in the case of mitigating durational departures; if the presumptive sentence were seen

${ }^{27}$ However, Minnesota did adopt von Hirsch's view that the criminal history scale, and its effect on the presumptive sentence, should be "closed-ended": at some point (in Minnesota: when the defendant has six or more criminal history points), the defendant has reached the full "deserts" applicable to the offense of conviction and cannot receive any further enhancement for additional prior convictions (von Hirsch 1981a, pp. 61820). 
as exceeding desert, for utilitarian reasons, then such reasons should quite readily permit downward departure (bringing the sentence back to "pure" desert, or closer to it).

Thus except for the "dangerous offender" statutes, "modified just deserts" in Minnesota does not seem to mean "departure" from desert but rather a broader conception of what "desert" means. Like Morris's theory, Minnesota's broader conception of desert permits a wide range of deserved penalties, and a strong role for criminal history.

\section{B. Other Guiding Factors (Fine-Tuning) within Desert Limits}

This subsection, which examines Minnesota's approach to incorporation of various punishment rationales in sentencing policy, generally follows the examination of Morris's views on these subjects set out in Section IC above.

1. Rebabilitation. Minnesota, like Morris, agrees that rehabilitation should primarily be pursued out of prison. Thus the defendant's need for treatment in prison is not a sufficient reason to impose a prison term (i.e., it is not a basis for an upward dispositional departure), and prison release does not depend on an assessment of the inmate's progress in treatment. Under the original guidelines, prison programs were entirely voluntary, as Morris argued they should be, and good-time credits could not be denied for refusal to participate in treatment programs. Starting in 1993, the Minnesota legislature permitted the commissioner of corrections to define "disciplinary" rules to include not only violation of general "institution rules" but also refusals to work and "refusal to participate in treatment or other rehabilitative programs" (Minn. Stat. Annot. $\$ 244.05$, subd. $1 \mathrm{~b}[\mathrm{~b}]$ ). Thus to a limited extent, the inmate's willingness to participate in treatment programs can now affect the length of his or her prison term. It should be recalled, however, that Morris would allow inmates to be forced to participate in prison programs long enough to "know what it is about" (Morris 1974, pp. 18-19). In practice, this may be all that Minnesota requires. It is not clear how often Minnesota inmates are "ordered" into prison treatment or education programs (as opposed to being ordered to do something, including the option of accepting various institutional work assignments), nor is it known whether unamenable offenders expelled from prison programs continue to forfeit good-time credits.

Both Morris and Minnesota also permit rehabilitative assessments to 
determine conditions of stayed sentences and of postprison supervised release.

"But"-Morris might be critical of the rehabilitation-related concepts of "amenability" and "unamenability" to probation, which Minnesota cases recognize as a basis for aggravated and mitigated dispositional departures. Morris generally opposes all individualized assessments of treatment needs and receptivity, progress toward cure, and dangerousness.

However, in discussing unamenable-to-probation departures (imposition of prison, instead of the presumptive stayed term), Morris did suggest that upward departures might be appropriate in "a few such cases" (Morris 1982, p. 176). Morris was specifically addressing departures based on mental illness, but he might be willing to consider other offender characteristics which require enhanced severity (within desert limits). As noted previously, unamenability departures are entered in less than one percent of presumptive stay cases; thus at least in terms of frequency, Minnesota practice is consistent with Morris's theory. Morris has also argued that greater severity is appropriate when "other less restrictive sanctions have been frequently or recently applied to this offender" (Morris 1974, pp. 60, 79-80). Many "unamenable-toprobation" departures (including the leading Park case) are based on prior failures to complete probation.

Morris did not specifically discuss mitigating "amenability" departures (i.e., granting of probation, instead of the presumptive prison term), but he did address two factors which sometimes underlie a finding of amenability to probation: the offender's support of his wife and children and his employment at the time of sentencing. At one point, Morris seems to completely rule out consideration of either factor (Morris 1982, p. 186); at another point, he admits that as a judge he would grant mitigation based on family support, but would not say why (Morris 1982, p. 196). As for employment at sentencing, Morris later appeared to agree that this factor sometimes permits a different form of punishment, and perhaps also somewhat lower severity: "To insist on equal suffering for Criminal B [the more fortunate, employed defendant] because of the adverse social conditions of Criminal $\mathrm{A}$ is to purchase an illusory equality at too high a price. It is a levelling down and benefits neither Criminal A nor the community. The criminal law cannot rectify social inequalities; those inequalities will inexorably infect rational punishment policies. But this hypothetical situation leaves an uneasy sense of moral imbalance and forces us to the consideration 
of how deserved punishments can operate fairly in a world of social inequality" (Morris and Tonry 1990, pp. 102-3). It should also be noted that amenability mitigations are consistent with Morris's more flexible approach to minimum sanction severity and help to achieve several of his goals: preservation of the offender's social and community ties, parsimony, and "mercy."

Like Morris, Minnesotans are conflicted and ambivalent about allowing social and economic factors to influence sentencing. The guidelines formally rule out any consideration of family or employment status, but these factors find considerable acceptance in practice and are indirectly sanctioned by the amenable-to-probation case law.

Finally, as to both types of amenability departure, Morris would certainly be sympathetic to the practical realities of implementing sentencing reforms: Minnesota trial judges, attorneys, and probation officers believe strongly in the appropriateness of amenability departures. Morris is a realist. Thus he might very well conclude that, in a heavily treatment-oriented state like Minnesota, it is wiser to permit (and then seek to regulate) amenability departures, rather than attempt to prohibit them; total prohibition in this context, as in many others, only invites subterfuge and evasion (Morris and Hawkins 1977, p. 21; Morris 1982, p. 158; Morris 1992, p. 139).

2. Incapacitation. Minnesota and Morris both sharply limit the extent to which individualized predictions of offender "dangerousness" may affect sentencing severity. Morris would never allow sentences to be increased on this basis above maximum desert and would very rarely permit enhancement within the desert range; however, he would permit some "anamnestic" predictions of risk (based on the offender's past behavior) to affect conditions of probation or parole.

Similarly, Minnesota permits dangerousness considerations to affect probation conditions, as well as the selection of the precise prison duration within the range of presumptive executed prison terms. The Minnesota guidelines prohibit aggravated durational departures based on offender dangerousness. However, recent "dangerous offender" statutes appear to permit enhancement of duration without regard to guidelines measures of desert, for certain narrowly defined groups of offenders.

Although upward dispositional departures cannot be based solely on a finding of offender dangerousness, such departures (as well as probation revocations) are sometimes based on a finding of "unamenability" to probation. Such a finding, in turn, is often supported in part by con- 
cerns that the offender is too dangerous to remain on probation. Morris would only support such enhancements if the prison term imposed does not exceed the upper limits of desert and if dangerousness assessments are limited to rare cases. These conditions appear to be met, in Minnesota; "unamenability" departures are very rare and do not appear to exceed the maximum deserts of presumptive stay defendants (as measured by the duration of the prison term for that grid cell).

3. Failure of Prior, Lesser Penalties; Categoric Recidivist Enbancements. Morris supports increased punishment (within desert limits) when "other less restrictive sanctions have been frequently or recently applied to this offender" (Morris 1974, pp. 60, 79-80). He also accepts enhanced punishment for recidivists as a group, seeing such enhancement as justified on both incapacitative and desert grounds (Morris 1982, pp. 162-63).

Minnesota occasionally permits aggravated dispositional departure based on defendant "unamenability" (which, in turn, is often based on prior failures to successfully complete probation). Minnesota also strongly links punishment severity to criminal history.

4. General Deterrence. Morris would permit enhancement for deterrent purposes (exemplary punishment) within the range of deserved penalties. Minnesota permits consideration of special needs for deterrence, within the range of presumptive executed prison terms, and in deciding on conditions of probation. Consistent with Morris's views, special needs for deterrence are not a proper basis for aggravated durational departure; such departures must be desert-based.

5. Equality (Uniformity). Minnesota and Morris agree that equality is an important goal but appear-at least on first inspection-to differ as to just how important it is. Morris states that equality is only a "guiding" principle, which will often be "trumped" by other considerations-especially "parsimony." The Minnesota Guidelines Commission identified uniformity as a major goal (Minnesota Sentencing Guidelines Commission 1984, pp. v, 33-53).

However, the Minnesota commission also recognized the goal of case-level parsimony which, because it allows sentences to depend on case-specific utilitarian needs, is often in conflict with equality (Tonry 1994, p. 62). Moreover, the commission has provided very little guidance as to the specific type or severity of nonimprisonment sanctions and has not tried to regulate prosecutorial charging and plea bargaining, which permit considerable "adjustment" of the commission's 
seemingly strict prison commitment and duration presumptions. Minnesota case law has added additional flexibility to the commission's rules. Thus in practice, Minnesota's system seems to be much closer to Morris's theory than to von Hirsch's in terms of the importance of equality.

6. Parsimony and Community-Based Sentencing. Both Morris and Minnesota accept the principle of parsimony: a preference for the least restrictive alternative consistent with the purposes of the particular sentence. Morris and Minnesota both prefer nonprison sanctions and strongly support community-based sentencing. As noted in Section III above, nonprison sentences constitute about 80 percent of felony sentences in Minnesota. Furthermore, mitigating departures far outnumber aggravated departures, under the guidelines, and the difference is even greater when de facto mitigating departures (achieved by charging discretion) are included (Frase 1993a, pp. 299-303, 317-18).

"But"-Morris's concept of parsimony appears to apply to all issues of sentencing, including conditions of probation, whereas the Minnesota commission's statement of this principle only seems to apply to the use of custodial sentences (Minnesota Sentencing Guidelines Commission 1995b, \I[3]). Also, Morris implies a general preference in favor of sentencing toward the low end of the "desert" range, and he may further assume that judges will use the bottom of that range as a starting point. In Minnesota, the "starting point" for sentencing of cases falling below the disposition line is the midpoint of the range of presumptive prison terms; for cases falling above the disposition line, no specific guidance or starting point is provided.

However, in practice Minnesota judges prefer to use the lower half of the available range of custodial terms. Thus in over three-quarters of the grid cells below the disposition line, the average length of prison terms imposed is less than the presumptive midpoint for that cell (Minnesota Sentencing Guidelines Commission 1995a, pp. 31, 51). As for cases above the disposition line, prison terms are rarely imposed, and the duration of jail terms imposed is modest (Minnesota Sentencing Guidelines Commission 1995a, pp. 21, 32): in only two of these twenty-six cells is the average duration greater than half of the maximum (twelve-month) jail term allowed (and average jail durations are far lower than the presumptive stayed prison term, in all grid cells). All of these judicial preferences for "low end" sentencing would appear even stronger if custody durations were analyzed relative to the higher- 
severity grid cells in which many of these defendants would have been convicted had they not received charging leniency (Frase 1993a, pp. 301-3, 317-18).

"But"- Morris would still probably say that Minnesota relies too heavily on jail terms and should instead use fines and other intermediate sanctions (Morris and Hawkins 1970, pp. 142-43; Morris and Tonry 1990, p. 79). About two-thirds of convicted felons in Minnesota now receive a local jail sentence. Moreover, the frequency of such sentences has grown considerably since guidelines sentencing began-in 1978, only 35 percent of felons received a jail sentence (Minnesota Sentencing Guidelines Commission 1995a, p. 21). As discussed more fully below, Morris would also lament the lack of any limits or guidelines for the use of jail terms.

Morris would probably appreciate that Minnesota uses jail terms in many cases where other states impose prison (Frase 1993a, p. 332, n. 120); thus he might agree that, if a custody term is deemed necessary, it is better that it be shorter and served closer to the defendant's home community. It should also be recalled that, even when jail inmates are counted, Minnesota's arrest-based custodial sentencing rate (inmates per weighted adult arrest) remained constant throughout the 1980s (while the rate for the nation as a whole increased by 80 percent); Minnesota's jail population, as well as its prison population, increased only as much as would be expected, given increased arrests and felony caseloads. It thus appears that the increase in felony jail sentencing was balanced by decreased use of jails for pretrial detention and misdemeanor sentencing. Such a substitution effect is a very defensible allocation of limited resources.

7. Rewarding Guilty Pleas and Otber Forms of Cooperation. Minnesota and Morris both permit good-time credits, in recognition of the need to maintain order in prison, once parole release discretion has been eliminated.

The Minnesota Guidelines Commission, like Morris, was concerned about disparity resulting from plea bargaining. The guidelines specify that "the exercise of constitutional rights by the defendant during the adjudication process" may not be a basis for departure (Minnesota Sentencing Guidelines Commission 1995b, § II.D.1.e). However, this carefully worded language does not prohibit the granting of leniency to defendants who waive, rather than "exercise," their rights. In practice, the defendant's plea remains a major factor in the granting of formal mitigating departures and is undoubtedly at least as strong a factor 
in charge reductions which produce de facto mitigating departures; plea bargaining is "alive and well" in Minnesota (Frase 1993a, pp. 310, 316-19).

Morris advocated stricter "regulation" of guilty-plea-based sentences, by means of judicially supervised "settlement" conferences. However, he appeared to assume that some degree of sentence mitigation would continue to be available in such conferences. He would also support the commission's implicit judgment that plea-rewarding mitigations are not as bad as trial-punishing aggravations (in part because, under both the Minnesota and Morris approaches, minimum-severity limits are more flexible), and he would appreciate that plea-bargained mitigations are one of the most common vehicles for achieving parsimony and "mercy" in sentencing.

The pervasive need to reward guilty pleas and other forms of defendant cooperation has important theoretical implications, in the Morris-von Hirsch debate. All modern adjudication and sentencing schemes depend to a great extent on the cooperation of defendants. Before and at trial, defendants must be promised leniency to induce and reward guilty pleas, jury trial waivers, testimony against other defendants, and so forth. At sentencing, the court must initially "underpunish" (give defendants less than they deserve) - not only to reward the defendant's cooperation up to that point but also to induce further cooperation (in holding employment, family support, restitution, treatment, supervision, etc.) and leave room for subsequent tightening of sanctions (e.g., by revocation of probation or loss of goodtime credits) if the defendant fails to cooperate.

Although some forms of cooperation might be seen as reducing the defendant's "deserts" (at least under a broad definition of that term), many forms do not; society often needs, and must reward, cooperation whether or not mitigation is deserved. Thus in practice, modern systems of law enforcement and punishment always function according to a "limiting" retributive model-most defendants $d o$ cooperate, at least to some extent, and thus receive less than their full "just deserts." In the real world of sentencing, a system of strict "defining" desert is unworkable. Moreover, any attempt to impose such a strict system is very likely to result in the imposition of excessive and undeserved severity-on defendants who refuse to cooperate. The position of Morris and other limiting retributivists is clear: punishment in excess of desert is unacceptable; excessive leniency is a less serious moral and political problem. The approach 
is both practical and principled; it is deliberately "biased" in favor of defendants, for reasons similar to those underlying the requirement of proof beyond a reasonable doubt.

\section{Other Important Sentencing Issues}

At least in stayed prison cases (over three-quarters of presumptive terms, and about 80 percent of actual sentences), Minnesota follows Morris's proposal that the judge should first decide the sentencing purpose or purposes to be served and should then select a package of intermediate sanctions designed to parsimoniously achieve those purposes.

In presumptive prison cases Minnesota judges have much less choice, at least formally. The judge must ordinarily sentence within a very narrow range of prison terms and may consider only whether exceptional factors of desert justify an aggravated or mitigated durational departure; or whether the defendant's "amenability to probation" (or, rarely, exceptionally mitigated culpability) justifies a mitigated dispositional departure. However, Morris did agree that presumptive prison, with few case-level options, is appropriate for the most serious cases. He would draw the line at cases presumptively punished with at least twenty-four months of actual incarceration (i.e., after subtraction of good-time credits). In Minnesota, most of the presumptive prison cases falling below the disposition line have presumptive minimum prison terms (after deduction of maximum good-time credit) at least this long: thirty-five of the forty-four grid cells below the line have presumptive minimum durations of at least twenty-four months. ${ }^{28}$

1. Nature and Scope of Guidelines. Morris felt that additional guidance could be provided to trial courts by the use of multiple presumptions or "bands" on the sentencing grid; for example, he expressed approval of a four-band grid: never prison; presume no prison, absent departure; permit either prison or community-based sanctions; and always prison (Morris and Tonry 1990, pp. 60, 77).

Minnesota's grid only has two formal "bands": presume no prison and presume prison. However, in practice, four bands are clearly discernible, year after year. In the upper left corner of the grid, there are

\footnotetext{
${ }^{28}$ Minimum prison terms for presumptive commit cases falling above the disposition line (mainly weapons and recidivist sex offenders) are shorter. However, departure rates are extremely high in these cases (Frase 1993a, p. 309), so judges in practice exercise broad discretion in the selection of sentencing purposes and alternatives.
} 
several cells in which prison is almost completely absent; in the bottom two rows (murder cases), prison is almost always imposed; in the center of the grid, on either side of the disposition line, are two bands of cells with very high departure rates (aggravated departures, in cells just above the line; mitigated departures, just below) (Frase 1993a, p. 323 [1989 data]; Minnesota Sentencing Guidelines Commission 1995a, p. 21 [1993 data]).

"But"- there remains one very important departure from Morris's theory: Minnesota has declined to enact any guidelines, or even any "equivalency" or "exchange" rates, for nonprison sanctions. The Minnesota commission has considered the possibility of such guidelines on several occasions but has declined to adopt them-primarily because of massive resistance of attorneys, judges, and probation officers, but also due to a lack of commission consensus on specific stay guidelines. Experience under the guidelines has clearly shown that, where field resistance is high and consensus is lacking, guidelines rules have been widely evaded (Frase 1993a, p. 337). Morris thus would appreciate the commission's dilemma and might hesitate to impose highly unpopular rules.

However, Morris would still probably insist that some form of guidance is feasible and desirable here. He would be particularly interested in guidelines that limit the maximum aggregate severity of stay conditions (using a point system and equivalency scales), and he might also want to set upper limits on jail sentences, in each guidelines cell. As I have argued elsewhere at greater length (Frase 1993c, pp. 19-23), stay guidelines would prevent unjustly severe sentences, would encourage substitution of noncustodial sanctions, and would give courts more concrete guidance in assessing the overall "onerousness" of stay conditions, for purposes of deciding when defendants may demand execution of the stayed prison term (State $v$. Randolph, 316 N.W.2d 508 [Minn. 1982]).

At the same time, I have argued that there are some very serious hurdles to overcome in enacting stay condition guidelines-especially those that impose minimum sanction severity. Such guidelines might prove undesirable for one or more of the following reasons (most of which Morris would probably accept):

a. Stay limitations would make the guidelines much more complex, whereas a major goal of the Minnesota commission has always been simplicity of application (Frase 1993a, pp. 281-82). Simplicity serves to promote broader understanding and acceptance of the rules and to 
reduce errors of application. Indeed, the unpopularity of the federal sentencing guidelines may be due, at least in part, to their complexity. Morris has recognized that, in general, "simpler is better" (Morris and Tonry 1990, p. 78); at some point, the cost of further complexity outweighs any added benefits.

$b$. What are the benefits here? Given the upper limits already imposed by the Randolph case, the frequency and degree of disparity in the imposition of stay conditions may not be very great and may seem less troubling than disparity in the imposition and duration of prison terms. Morris himself has argued that equality is only one consideration and may be outweighed by other factors. Minnesotans appear to agree and have been content with the current system for over fifteen years. Like Morris, and unlike von Hirsch, Minnesotans do not seem to feel that occasional, or even frequent, imposition of more severe stay conditions on less culpable offenders is "too unfair." If desert and equality goals do not require closer regulation in this context, then trial courts should retain discretion to tailor stay conditions to the particular purposes at sentencing and should remain free to mitigate punishment for reasons of parsimony-to avoid imposing greater severity when it would not serve any practical purpose.

c. Minimum requirements for stay condition severity are designed to increase the onerousness of stay conditions. But stricter or more numerous stay conditions inevitably mean an increase in the frequency of probation violations and thus at least some increase in prison commitment rates (Tonry 1994, p. 61). Minimum stay condition requirements also tend to reduce the court's reserved sentencing power, on revocation of the stay. If (as seems only fair) defendants are credited with the equivalent, in prison days, of the stay conditions already completed (von Hirsch, Wasik, and Greene 1989, p. 610)_-just as they are now credited with any days spent in local jail-then more onerous stay conditions mean that there is less deserved punishment "left over" to use as a sanction for violation of such conditions. Conversely, less severe stay conditions reduce the risk of noncompliance and increase the incentive to fulfill all conditions (because the defendant faces swift execution of most of the stayed prison term).

d. Minimum stay conditions-especially jail terms—risk overloading the available corrections resources in many counties, especially those which are locally funded. Moreover, periodic overload is a greater risk at the local than at the state level; given the smaller scale of local operations, criminal caseloads and available capacities are probably subject 
to wider day-to-day fluctuations than occur in larger, statewide systems.

e. Flexibility in the imposition of stay conditions permits a desirable degree of "local control," so that sentencing policy and the use of local resources may reflect important variations in local values and traditions.

$f$. Experiments with stay guidelines in other states suggest some difficulty in achieving consensus as to specific equivalency or exchange rates for widely differing sanction types.

g. Stay guidelines-especially minimum severity requirementswould be very difficult to enforce consistently. Prosecutors are already very unlikely to appeal leniency in the application of the existing prison guidelines (Frase 1991a, pp. 752-73; Frase 1993a, pp. 316-19). Prosecutors would be even less likely to appeal departures from stay guidelines, given the lesser degree of severity and disparity involved. Defendant appeals (of sentences exceeding stay condition maxima) are more likely, but extremely onerous stay conditions are already substantially limited by the Randolph rule.

$b$. If lower limits on stay condition severity are unenforceable, and perhaps undesirable, could upper limits alone be adopted? Or would such a proposal fail to gain sufficient bipartisan support within the commission, and elsewhere, thus forcing the adoption of minimum severity limits?

In sum, it will be quite difficult to implement and enforce any comprehensive system regulating conditions of stayed sentences, especially a system imposing minimum requirements of sanction severity. Morris would probably agree with many of the reasons why Minnesota has thus far declined to adopt any such system. Nevertheless, he might still argue for a more limited version of stay guidelines.

2. Sentencing Appeals. To maximize guidance to trial judges in sentencing, Morris and Minnesota both support the development of a substantial body of appellate case law-a "common law of sentencing." Minnesota case law extensively defines the desert and nondesert factors which may appropriately be considered as a basis for departure, although it has done little to address fine-tuning within the range permitted by presumptive disposition and duration rules. In the case of presumptive commit cases, this may be because the ranges are already quite narrow. The ranges are much broader in presumptive stay cases; the problems of providing detailed guidance for these cases are discussed above. 
To make appellate review of sentences more effective, Morris proposed that the trial court should state reasons for its sentence, if an appeal is filed. Minnesota requires the trial court to state reasons whenever the sentence is a departure from the guidelines (which, as a practical matter, is the only time a sentence is likely to be appealed, given the Minnesota Supreme Court's reluctance to reverse nondeparture sentences; State v. Kindem, 313 N.W.2d 6 [Minn. 1981]).

3. Parole and Prison Population Control. Given Minnesota's and Morris's rejection of the "rehabilitative ideal" of coerced, in-prison treatment, and their further rejection of most forms of selective incapacitation via imprisonment, it was natural that both would eventually favor abolition of discretionary parole release. Both also recognized the need for additional mechanisms to control prison population size, if parole is abolished.

"But"-Minnesota approached the problem of prison population control in a manner different than Morris anticipated. Morris had initially proposed to retain parole, as a prison population "safety valve" (but with parole guidelines and the setting of target release dates soon after the offender's arrival in prison). Like almost all other early proponents of sentencing reform, Morris did not foresee the use of sentencing guidelines as a means of "front-end" resource management, via sophisticated computer-based projections of the prison population impact of proposed guidelines. Minnesota pioneered this approach, and it has been a central feature of state guidelines systems since the mid-1980s (Frase 1995b, pp. 173-74, 175-76). However, Morris did foresee and appreciate the value of having prison commitment and duration decisions made by a body insulated from direct electoral political pressures.

\section{Conclusion}

Although the Minnesota guidelines give greater emphasis to retributive values than did the previous, indeterminate sentencing regime, Minnesota guidelines sentencing is, and has always been, much closer to Morris's "limiting retributive" approach than to the more "defining" desert theory advocated by von Hirsch. Retributive values set firm upper limits on sanction severity in Minnesota but rather weak lower limits (or none at all). Judges and attorneys retain substantial discretion to consider utilitarian sentencing goals and to vary the form and severity of the sentence. Uniformity and proportionality of sentencing have increased under the guidelines. But Minnesotans appear to agree with 
Morris that these are only two of the many important goals of, and at, sentencing. All in all, Minnesota's hybrid sentencing system has achieved an appropriate and stable compromise, balancing the values of uniformity versus case-level flexibility, retributive versus utilitarian goals, and public protection versus parsimony and fiscal limitations (Frase 1993c, pp. 13-33). Such balance is the essence of Morris's approach.

How was it that Minnesota policy makers came to adopt so much of Morris's theory without, as far as this writer can tell, ever specifically citing his writings? It is possible that Morris's theory indirectly affected policy developments in Minnesota through his strong influence on the thinking of other scholars and reformers in the late 1970sespecially the drafters of the second edition of the American Bar Association Standards on Sentencing (American Bar Association 1979; von Hirsch 1981b, pp. 783-84). Of course, the currents of influence have also flowed in the other direction: Morris continued to develop his theory after the Minnesota guidelines were implemented. Although his later writings clearly built on themes which he had begun to develop many years before, they were also strongly influenced by the new concepts and procedures being pioneered in Minnesota (and later, in many other states, and in the federal courts).

In seeking to understand the remarkable correspondence between Morris's theory and the theory that has evolved in Minnesota, it is important to recognize that Minnesota's current sentencing system is not the product of any single person, group, or agency. Rather, the Minnesota approach was the combined result of decisions made, over a period of several years, by the legislature, the guidelines commission, the supreme court, trial courts, prosecuting and defense attorneys, correctional officers, and perhaps even victims and defendants. These key actors not only did not consult Morris, they generally did not consult each other in any systematic way. Yet they settled on a theory of punishment which is coherent, balanced, and workable. Perhaps the best explanation, then, for the many similarities between Minnesota's and Morris's theory is to be found in Morris's empirically based, consensus-seeking, "from-the-ground-up" approach. Morris has always sought guidance in the actual practices of system actors and has tried to craft an approach which will gain broad acceptance (Morris and Tonry 1990, pp. 87-88, 108). (If only the drafters of the muchcriticized federal guidelines had followed this approach.) Morris's theory became reality in Minnesota because Morris was articulating fun- 
damental and widely held values that will, and must, be accommodated in any progressive sentencing reform which is likely to be adopted and to survive. Whether such a sentencing theory could be adopted and survive in a less politically progressive state, or in a more punitive age, is another matter.

What will the future hold, in Minnesota? Will Morris's humane and efficient model continue to survive? No American state-Minnesota included-is immune from periods of "crime wave" hysteria, "law and order" political posturing, and strong public pressure to increase criminal penalties. In the late 1980s, Minnesota began to experience alarming increases in rates of violent crime-despite the fact that violent crime penalties were already quite severe. Drug crime rates also increased, as the epidemic of crack cocaine, the "War on Drugs," and the problems of deteriorating inner cities finally "arrived" in Minnesota. In 1986, the Minnesota legislature began a steady increase in the severity of drug penalties (Minnesota Sentencing Guidelines Commission 1992, pp. 3-5); further major increases in sentencing severity for violent crimes were enacted by the sentencing guidelines commission in 1989 and by the legislature in 1989 and 1992 (Frase 1993b, pp. 35963).

Von Hirsch has suggested that these increases in severity could be the result of Minnesota's more flexible, Morris-style "limiting retributive" model - or, at least, that such a model provides a weaker basis for criticism than von Hirsch's more restrictive concept of desert (von Hirsch 1994, pp. 39-45). It is certainly true that von Hirsch's strict requirements of ordinal desert, if accepted in Minnesota, would have made it more difficult to selectively increase penalties for drug and violent crimes. Readers will have to decide for themselves whether von Hirsch's one-dimensional theory could ever have been implemented in Minnesota, and even if it could have, whether such a theory would have better helped Minnesota to resist very strong political pressures to increase penalties. The danger under von Hirsch's theory is that such pressures will lead to an escalation of the entire penalty scale, resulting in unwanted (and very expensive) increased severity for lesser offenders or massive increases in departure rates and disparity for such offenders.

It should also be kept in mind that, notwithstanding recent increases in sentencing severity and inmate populations, Minnesota sentencing remains - by any American standard of comparison-a model of the "parsimonious" use of custodial sanctions. Von Hirsch would only 
permit parsimony to be considered by the legislature and the sentencing commission, and only in the determination of "cardinal" sentencing policy issues. But parsimony is too important a concept to be so limited in its application. It encourages moderation in sentencing and serves as an essential counterweight to the strong, ever-present political pressure to escalate penalties beyond what is necessary (and often, beyond what the public is actually willing to fund). For this reason, Minnesota and Morris recognize the value of parsimony in all sentencing policy and application decisions.

It must be recognized, however, that much of Minnesota's success in holding the line in sentencing severity during the 1980s was due to another factor: the high priority which the Minnesota sentencing guidelines commission placed on avoiding prison overcrowding. Minnesota's "capacity constraint" (the goal of never exceeding 95 percent of current or planned capacity) was a very wise strategy, reflecting two fundamental truths about American sentencing in the late twentieth century. First, expansion of prison capacity is a slow process, and legislators often fail to provide sufficient funds in time to avoid significant overcrowding; the best way to avoid such overcrowding is to adopt the conservative assumption that $n o$ further prison expansion will be provided. Second, all American jurisdictions (state and federal) already have substantial capacity to incarcerate; by any rational standard (and certainly, by any international standard; Frase $1995 c$, p. 275; Frase and Weigend 1995, pp. 346-48), American jurisdictions are already making excessive use of custodial sanctions. The question is, thus, not whether more capacity is needed but rather whether better use could be made of the existing capacity. The assumption of no further growth in capacity encourages the sentencing commission and other policy makers to explore alternatives to incarceration that may be just as effective and are almost always cheaper and more humane (Morris and Tonry 1990). Such an assumption, coupled with sophisticated, computer-generated inmate population projections, also forces advocates of greater severity, both within the commission and outside it, to take responsibility for the fiscal impact of their proposals, in terms of increased taxes or reduced penalties for other offenders (Parent 1988, pp. 43-44).

Thus it may very well be that Morris's principle of parsimony would not have been effective in Minnesota, if it had not been combined with "capacity-based" sentencing policy. But at the same time, capacitybased sentencing policy may not work without case-level parsimony. 
Prison population projections are still an inexact science, and the Minnesota commission has often seriously underestimated the impact of rising caseloads, changing prosecutorial charging practices, legislative changes, and other factors which increase prison populations (Minnesota Sentencing Guidelines Commission 1984, pp. 90-91). Fortunately, the commission also underestimated various mitigating factors (especially rates of downward dispositional departure and charge reductions; Frase 1991a, p. 735). If the guidelines had not included so many possibilities for case-level mitigation, it is very likely that sentencing severity, inmate populations, and prison overcrowding would have increased substantially.

Minnesota's pioneering sentencing reform has now been emulated in almost twenty states and has also recently been endorsed by the American Bar Association (American Bar Association 1993; Frase 1995a, pp. 169, 197; Frase 1995b, p. 174). Increasingly, states are turning to guidelines as a means of gaining better predictions of, and control over, rapidly escalating prison populations and correctional costs (Frase 1995b, p. 175). But reformers should not lose sight of the original goal of sentencing guidelines: to promote more rational and fair sentencing. They should look to Minnesota not only for guidance in controlling prison populations but also for an example of a balanced, humane, and effective sentencing system. And they should look to Morris's writings for an original and often eloquent statement of the key features of, and rationale behind, the Minnesota "model."

REFERENCES

Allen, Francis A. 1964. The Borderland of Criminal 7ustice: Essays in Law and Criminology. Chicago: University of Chicago Press.

1981. The Decline of the Rebabilitative Ideal: Penal Policy and Social Purpose. New Haven, Conn.: Yale University Press.

American Bar Association. 1968. Standards Relating to the Administration of Criminal 7ustice: Sentencing Alternatives and Procedures. Chicago: American Bar Association.

1979. Standards Relating to the Administration of Criminal Fustice: Sentencing Alternatives and Procedures. 2d ed. Washington, D.C.: American Bar Association.

- 1993. ABA Standards for Criminal fustice: Sentencing. 3d ed. Washington, D.C.: American Bar Association. 
American Law Institute. 1962. Model Penal Code, Proposed Official Draft. Philadelphia: American Law Institute.

Ashworth, Andrew J. 1992. Sentencing and Criminal fustice. London: Weidenfeld \& Nicolson.

Bottoms, Anthony. 1995. "The Philosophy and Politics of Punishment and Sentencing." In The Politics of Sentencing Reform, edited by Rod Morgan and Chris Clarkson. Oxford: Oxford University Press.

Bureau of Justice Statistics. 1995. Prisoners in 1994. Washington, D.C.: U.S. Department of Justice, Bureau of Justice Statistics.

Cragg, Wesley. 1992. The Practice of Punisbment: Towards a Theory of Restorative Fustice. London: Routledge.

Dailey, Debra L. 1993. "Prison and Race in Minnesota." University of Colorado Law Review 64:761-80.

Federal Bureau of Investigation. 1981. Crime in the United States: Uniform Crime Reports, 1980. Washington, D.C.: U.S. Government Printing Office. - 1994. Crime in the United States: Uniform Crime Reports, 1993. Washington, D.C.: U.S. Government Printing Office.

Frase, Richard S. 1991a. "Sentencing Reform in Minnesota, Ten Years After: Reflections on Dale G. Parent's Structuring Criminal Sentences: The Evolution of Minnesota's Sentencing Guidelines." Minnesota Law Review 75:727-54.

- 1991b. "Defendant Amenability to Treatment or Probation as a Basis for Departure under the Minnesota and Federal Sentencing Guidelines." Federal Sentencing Reporter 3:328-33.

-. 1993a. "Implementing Commission-Based Sentencing Guidelines: The Lessons of the First Ten Years in Minnesota." Cornell fournal of Law and Public Policy 2:279-337.

1993b. "The Role of the Legislature, the Sentencing Commission, and Other Officials under the Minnesota Sentencing Guidelines." Wake Forest Law Review 28:345-79.

. 1993c. "The Uncertain Future of Sentencing Guidelines." Law and Inequality 12:1-42.

- 1993d. "Prison Population Growing under Minnesota Sentencing Guidelines." Overcrowded Times 4(1):1, 10-12.

—. 1994. "Purposes of Punishment under the Minnesota Sentencing Guidelines." Criminal fustice Etbics 13:11-20.

—. 1995a. "Sentencing Guidelines in Minnesota and Other American States: A Progress Report." In The Politics of Sentencing Reform, edited by Rod Morgan and Chris Clarkson. Oxford: Oxford University Press. . 1995b. "State Sentencing Guidelines: Still Going Strong." Fudicature 78:173-79.

. 1995c. "Sentencing Laws and Practices in France." Federal Sentencing Reporter 7:275-80.

Frase, Richard S., and Thomas Weigend. 1995. "German Criminal Justice as a Guide to American Law Reform: Similar Problems, Better Solutions?" Boston College International and Common Law Review 18:317-60.

Goodstein, Lynne. 1983. "Sentencing Reform and the Correctional System." Law and Policy Quarterly 5:478-501. 
Heinz, Anne M., and Wayne A. Kerstetter. 1979. "Pretrial Settlement Conference: Evaluation of a Reform in Plea Bargaining." Law and Society Review 13:349-66.

Miller, Marc, and Norval Morris. 1986. "Predictions of Dangerousness: Ethical Concerns and Proposed Limits." Notre Dame Fournal of Law, Etbics, and Public Policy 2:393-444.

Minnesota Sentencing Guidelines Commission. 1980. Report to the Legislature. St. Paul: Minnesota Sentencing Guidelines Commission.

- 1984. The Impact of the Minnesota Sentencing Guidelines: Three-Year Evaluation. St. Paul: Minnesota Sentencing Guidelines Commission.

- 1989. Report to the Legislature on Three Special Issues (Feb. 1989). St. Paul: Minnesota Sentencing Guidelines Commission.

- 1991. Report to the Legislature on Intermediate Sanctions. St. Paul: Minnesota Sentencing Guidelines Commission.

- 1992. Report to the Legislature on Controlled Substance Offenses. St. Paul: Minnesota Sentencing Guidelines Commission.

- 1995a. Sentencing Practices: Highlights and Statistical Tables; Felony Offenders Sentenced in 1993. St. Paul: Minnesota Sentencing Guidelines Commission.

- 1995b. "Sentencing Guidelines and Commentary." In Minnesota Statutes Annotated, chap. 244 (Appendix). St. Paul, Minn.: West.

Morris, Norval. 1951. The Habitual Criminal. New York: Longmans, Green.

- 1953. "Sentencing Convicted Criminals." Australian Law fournal 27: $186-200$.

- 1964. "Penal Sanctions and Human Rights." In Studies in Criminal Law, edited by Norval Morris and Colin Howard. Oxford: Clarendon.

Press.

. 1974. The Future of Imprisonment. Chicago: University of Chicago

- 1977a. "Punishment, Desert, and Rehabilitation." In Equal Fustice under Law. U.S. Dept. of Justice, Bicentennial Lecture Series, pp. 137-67. Washington, D.C.: U.S. Government Printing Office.

- 1977b. "Towards Principled Sentencing." Maryland Law Review 37: 267-85.

Press.

1982. Madness and the Criminal Law. Chicago: University of Chicago

1992. "Incapacitation within Limits." In Principled Sentencing, edited by Andrew von Hirsch and Andrew Ashworth. Boston: Northeastern University Press.

- 1993. "The Honest Politician's Guide to Sentencing Reform." In The Socio-economics of Crime and Zustice, edited by Brian Forst. Armonk, N.Y.: M. E. Sharpe.

Morris, Norval, and Gordon Hawkins. 1970. The Honest Politician's Guide to Crime Control. Chicago: University of Chicago Press.

. 1977. Letter to the President on Crime Control. Chicago: University of Chicago Press.

Morris, Norval, and Colin Howard, eds. 1964. Studies in Criminal Law. Oxford: Clarendon. 
Morris, Norval, and Marc Miller. 1985. "Predictions of Dangerousness." In Crime and 7ustice: A Review of Research, vol. 6, edited by Michael Tonry and Norval Morris. Chicago: University of Chicago Press.

Morris, Norval, and Michael Tonry. 1990. Between Prison and Probation: Intermediate Punishments in a Rational Sentencing System. New York: Oxford University Press.

Parent, Dale G. 1988. Structuring Criminal Sentences: The Evolution of Minnesota's Sentencing Guidelines. Stoneham, Mass.: Butterworth Legal Publishers.

Tonry, Michael. 1994. "Proportionality, Parsimony, and Interchangeability of Punishments." In Penal Tbeory and Penal Practice, edited by Antony Duff and Sandra Marshall. Manchester: Manchester University Press.

von Hirsch, Andrew. 1976. Doing Fustice: The Choice of Punishments; Report of the Committee for the Study of Incarceration. New York: Hill \& Wang.

- 1981a. "Desert and Previous Convictions in Sentencing." Minnesota Law Review 65:591-634.

. 1981b. "Utilitarian Sentencing Resuscitated: The American Bar Association's Second Report on Criminal Sentencing." Rutgers Law Review 33: 772-89.

- 1984. "Equality, 'Anisonomy,' and Justice: A Review of Madness and the Criminal Law." Michigan Law Review 82:1093-1112.

1985. Past or Future Crimes: Deservedness and Dangerousness in the Sentencing of Criminals. New Brunswick, N.J.: Rutgers University Press.

- 1987a. "The Enabling Legislation." In The Sentencing Commission and Its Guidelines, edited by Andrew von Hirsch, Kay Knapp, and Michael Tonry. Boston: Northeastern University Press.

- 1987b. "Structure and Rationale: Minnesota's Critical Choices." In The Sentencing Commission and Its Guidelines, edited by Andrew von Hirsch, Kay Knapp, and Michael Tonry. Boston: Northeastern University Press.

- 1992. "Proportionality in the Philosophy of Punishment." In Crime and fustice: A Review of Research, vol. 16, edited by Michael Tonry. Chicago: University of Chicago Press.

. 1993. Censure and Sanctions. Oxford: Clarendon. nal 7ustice Ethics 13:39-49.

- 1995. "Proportionality and Parsimony in American Sentencing Guidelines: The Minnesota and Oregon Standards." In The Politics of Sentencing Reform, edited by Rod Morgan and Chris Clarkson. Oxford: Oxford University Press.

von Hirsch, Andrew, Martin Wasik, and Judith Greene. 1989. "Punishments in the Community and the Principles of Desert." Rutgers Law Fournal 20: 595-618.

Zimring, Franklin, and Gordon Hawkins. 1973. Deterrence: The Legal Threat in Crime Control. Chicago: University of Chicago Press. 
